OPEN ACCESS

Edited by:

Paul Bodelier,

Netherlands Institute of Ecology (NIOO-KNAW), Netherlands

Reviewed by: Haiyan Chu,

Institute of Soil Sciences in Nanjing (UCAS), China

Yuting Liang,

Institute of Soil Science (CAS), China

Zhongjun Jia,

Institute of Soil Science (CAS), China

*Correspondence:

Hui L

huili@iae.ac.cn

Specialty section:

This article was submitted to

Terrestrial Microbiology,

a section of the journal

Frontiers in Microbiology

Received: 03 January 2017 Accepted: 10 October 2017

Published: 27 October 2017

Citation:

Yao $F$, Yang $S$, Wang $Z$, Wang $X$, Ye J, Wang $X$, DeBruyn JM, Feng $X$, Jiang $Y$ and Li H (2017) Microbial Taxa

Distribution Is Associated with

Ecological Trophic Cascades along an

Elevation Gradient.

Front. Microbiol. 8:2071.

doi: 10.3389/fmicb.2017.02071

\section{Microbial Taxa Distribution Is Associated with Ecological Trophic Cascades along an Elevation Gradient}

\author{
Fei Yao ${ }^{1,2}$, Shan Yang ${ }^{1,3}$, Zhirui Wang ${ }^{1,2}$, Xue Wang ${ }^{1,2}$, Ji Ye ${ }^{1}$, Xugao Wang ${ }^{1}$, \\ Jennifer M. DeBruyn ${ }^{4}$, Xue Feng ${ }^{1}$, Yong Jiang ${ }^{1}$ and Hui Li $^{1 *}$ \\ ${ }^{1}$ CAS Key Laboratory of Forest Ecology and Management, Institute of Applied Ecology, Chinese Academy of Sciences, \\ Shenyang, China, ${ }^{2}$ University of Chinese Academy of Sciences, Beijing, China, ${ }^{3}$ College of Land and Environment, \\ Shenyang Agricultural University, Shenyang, China, ${ }^{4}$ Department of Biosystems Engineering \& Soil Science, University of \\ Tennessee, Knoxville, TN, United States
}

The elevational pattern of soil microbial diversity along mountain slopes has received considerable interest over the last decade. An increasing amount of taxonomic data on soil microbial community composition along elevation gradients have been collected, however the trophic patterns and environmental drivers of elevational changes remain largely unclear. Here, we examined the distribution patterns of major soil bacterial and fungal taxa along the northern slope of Changbai Mountain, Northeast China, at five typical vegetation types located between 740 and 2,691 m above sea level. Elevational patterns of the relative abundance of specific microbial taxa could be partially explained by the oligotrophic-copiotrophic theory. Specifically, two dark-coniferous forests, located at mid-elevation sites, were considered to be oligotrophic habitats, with relatively higher soil $\mathrm{C} / \mathrm{N}$ ratio and $\mathrm{NH}_{4}^{+}-\mathrm{N}$ concentrations. As expected, oligotrophic microbial taxa, belonging to the bacterial phyla Acidobacteria and Gemmatimonadetes, and fungal phylum Basidiomycota, were predominant in the two dark-coniferous forests, exhibiting a mid-elevation maximum pattern. In contrast, the broad leaf-Korean pine mixed forest located at the foot of the mountain, Betula ermanii-dominated forest located below the tree line, and alpine tundra at the highest elevation were considered more copiotrophic habitats, characterized by higher substrate-induced-respiration rates and $\mathrm{NO}_{3}^{-}-\mathrm{N}$ concentrations. Microbial taxa considered to be so called copiotrophic members, such as bacterial phyla Proteobacteria and Actinobacteria, and fungal phylum Ascomycota, were relatively abundant in these locations, resulting in a mid-elevation minimum pattern. At finer taxonomic levels, the two most abundant proteobacterial classes, alpha- and beta-Proteobacteria, along with Acidobacteria Gp1, 2, 3, 15, and the Basidiomycotal class of Tremellomycetes were classified with the copiotrophic group. Gamma- and delta-Proteobacteria, Acidobacteria Gp4, 6, 7, 16, and Basidiomycotal class of Agaricomycetes were classified as oligotrophic taxa. This work uses the 
oligotrophic-copiotrophic theory to explain the elevational distribution pattern of the relative abundance of specific microbial taxa, confirming some of the existing trophic classifications of microbial taxa and expanding on the theory to include a broader range of taxonomic levels.

Keywords: microbial biogeography, soil bacteria, soil fungi, amplicon sequencing, microbial taxonomic survey, oligotrophic-copiotrophic theory, elevational gradient

\section{INTRODUCTION}

The oligotrophic-copiotrophic theory has been proposed as an ecological classification scheme for soil bacteria, predicting that copiotrophic taxa are more associated with greater labile carbon (C) pools and flourish in soils with higher net carbon mineralization rate, whereas the oligotrophic taxa dominate soils with lower organic carbon availability (Fierer et al., 2007). The soil carbon/nitrogen $(\mathrm{C} / \mathrm{N})$ ratio is also proposed as an important indicator of $\mathrm{C}$ availability (Wichern et al., 2007; Muller et al., 2017), with high $\mathrm{C} / \mathrm{N}$ ratio representing low $\mathrm{C}$ availability. According to this theory, a variety of dominant soil bacterial phyla, such as Proteobacteria (in particular Alphaand Beta-Proteobacteria) (Fierer et al., 2007; Francioli et al., 2016) and Firmicutes (Cleveland et al., 2007; Nemergut et al., 2010; Francioli et al., 2016) have been generally classified as copiotrophic microbes, whereas Acidobacteria (Smit et al., 2001; Fierer et al., 2012), Gemmatimonadetes (Cederlund et al., 2014), Verrucomicrobia (Janssen et al., 1997, 2002; Bergmann et al., 2011; Cederlund et al., 2014) and Chloroflexi (Phung et al., 2004; Ramirez-Villanueva et al., 2015) are typically classified as oligotrophic microbes. The trophic categorization of Actinobacteria has remained unclear thus far. Previous studies examining the response of Actinobacteria to nutrient additions have documented mixed results, with some studies reporting an increase in relative abundance (Ramirez et al., 2010, 2012; Pan et al., 2014), while others reported no change (Fierer et al., 2007; Zhao et al., 2014; Li et al., 2016).

Though the oligotrophic-copiotrophic theory has often been used to discuss the ecological roles of dominant bacterial phyla, it is less frequently applied to fungal taxa. Saprotrophic fungi are known to prefer nutrient-rich environments (Colpaert and vanTichelen, 1996) and play important roles in wood and leaflitter decomposition and nutrient cycling (Crowther et al., 2012; Kohler et al., 2015). In contrast, ectomycorrhizal (ECM) fungi usually grow under oligotrophic conditions, such as the deeper soil horizons (Lindahl et al., 2007). They typically have a slow growth rate (Hibbett et al., 2000), and have a limited capacity to affect the decomposition of organic materials (Kohler et al., 2015). Based on these previous findings, we proposed that ECM fungal taxa may be characterized as oligotrophic, while saprotrophic fungi may exhibit copiotrophic tendencies.

The distribution patterns of organisms and biological communities along elevational gradients is a fundamental subject in biogeography (Linnaeus, 1781; Bryant et al., 2008), because elevational gradients are characterized by distinct climate and ecological changes over short geographic distances. Studies have documented elevational patterns of diversity across a wide variety of taxonomic groups, such as trees, mammals, birds, insects, and nematodes (Bryant et al., 2008; Ohsawa and Ide, 2008; Pyrcz et al., 2009; Rowe, 2009; Zhang et al., 2012). With the application of molecular methods in microbial ecology, the elevational distribution patterns of soil microbial communities has received increasing attention over the last decade (Bryant et al., 2008; Fierer et al., 2011). A number of studies have documented decreasing alpha-diversity with elevation (Bryant et al., 2008; Bahram et al., 2012; Zhang et al., 2015), whereas others reported a maximum diversity at mid-elevations (Singh et al., 2012), or nonsignificant elevational patterns (Fierer et al., 2011; Roy et al., 2013; Shen et al., 2013, 2014; Singh et al., 2013; Geml et al., 2014; Wang J. T. et al., 2015). Since it is known that individual microbial taxa exhibit different life strategies, for example, Proteobacteria are usually active in metabolizing labile carbon (Fierer et al., 2007), while Acidobacteria tend to be associated with habitats with more recalcitrant carbon (Llado et al., 2016), determining the effects of elevational gradients on the relative abundances of specific microbial taxa maybe important for interpreting patterns of microbial diversity and understanding ecosystem functioning.

The elevational distribution patterns of the relative abundance of specific soil microbial taxa had garnered less attention, and thus mechanisms driving taxonomic distribution patterns are poorly understood. A study conducted in Mount Fuji, Japan demonstrated that Proteobacteria and Acidobacteria decreased in relative abundance with increasing elevation, whereas Actinobacteria, Chloroflexi, and Gemmatimonadetes showed a reverse trend (Singh et al., 2012). On Shennongjia Mountain in central China, which has the world's most well-preserved subtropical virgin and mature forest in a mid-latitudinal area, relative abundances of Acidobacteria, Actinobacteria, and Alphaproteobacteria was lowest at the middle elevations, while Verrucomicrobia and Betaproteobacteria exhibited the highest relative abundances at mid-elevation (Zhang et al., 2015). Observations from another subtropical forest in China (Lushan Mountain) also revealed that at mid elevations the relative abundance of Acidobacteria and Ascomycota was lowest and Proteobacteria and Basidiomycota were highest (Meng et al., 2013). Leotiomycetes, a dominant class within the Ascomycota, increased in relative abundance with elevation, exhibiting their highest relative abundance at high elevation in a tropical forest in the Peruvian Andes (Meier et al., 2010). Despite the increasing amount of descriptive data, mechanisms driving these distinct elevational patterns are not clearly discussed. It has been proposed that low $\mathrm{pH}$ could be an important factor associated with the prevalence of Acidobacteria in specific habitats (Singh et al., 2012). Moreover, the higher soil total carbon and $\mathrm{C} / \mathrm{N}$ ratio have been suggested to be closely associated with increasing 
Basidiomycota, and diminishing Ascomycota abundances (Meng et al., 2013).

The Changbai Mountain Natural Reserve, located along the border of China and North Korea, is one of the best preserved natural ecosystems in Northeast China. The vertical distribution of vegetation along the northern slope of Changbai Mt. mirrors the latitudinal vegetation gradient from temperate to polar zones on the Eurasian continent (Xu et al., 2004; Zhang et al., 2011), and thus presents an ideal site for investigating elevational distribution patterns of soil microbes. Five typical vegetation types, including broad leaf-Korean pine mixed forest (BL-KP) (740-1,100 m), Korean pine-spruce fir forest (KPSF) $(1,100-1,500 \mathrm{~m})$, Spruce Fir-Betula ermanii forest (SF-BE) (1,500-1,800 m), Betula ermanii forest (BE) (1,800-2,100 m) and Alpine tundra (AT) $(2,100-2,691 \mathrm{~m})$ were chosen for this study to elucidate the distribution patterns of dominant soil microbial taxa abundance along the northern slope of Changbai Mountain. We hypothesized that different vegetation types along the elevational gradients would select distinct soil bacterial and fungal communities, with copiotrophic taxa predominating in nutrient-rich forests and the predicted oligotrophic microbial taxa flourishing in nutrient-poor habitats. Specifically, we hypothesized that the two dark-coniferous forest sites (KP-SF and SF-BE) at mid-elevation would select for oligotrophic taxa because of the high $\mathrm{C} / \mathrm{N}$ ratio and lignin in needle litters (Knorr et al., 2005; Zhang et al., 2016), and thus, the low $\mathrm{C}$ availability in soil. As a result, these coniferous forests might be dominated by proposed oligotrophic microbial taxa. In contrast, forests with more broad leaf trees, including $\mathrm{BL}-\mathrm{KP}$ and $\mathrm{BE}$, would have higher proportions of copiotrophic microbial taxa. At the highest elevation, alpine tundra is typically considered oligotrophic because of harsh environmental conditions, including high solar radiation, low humidity, large daily temperature fluctuations, high wind exposure, and low soil nutrients (Freeman et al., 2009; King et al., 2012), and thus we predicted that the oligotrophic taxa would be predominant at the AT site.

The main objectives of our study were to: (1) document the taxonomic distributions of soil bacteria and fungi along an elevation gradient; (2) determine if distributions follow patterns predicted by the oligotrophic-copiotrophic theory; (3) correlate distribution patterns to edaphic factors which may help explain the ecological trophic cascades along an elevation gradient.

\section{MATERIALS AND METHODS}

\section{Site Description}

The experimental site is located in the Changbai Mountain Natural Reserve $\left(41^{\circ} 23^{\prime}-42^{\circ} 36^{\prime} \mathrm{N}, 126^{\circ} 55^{\prime}-129^{\circ} 00^{\prime} \mathrm{E}\right)$, Jilin Province, Northeast China. The Reserve has been protected from logging and other anthropogenic disturbances since it was established in 1960, and joined the World Biosphere Reserve Network under the UNESCO Man and the Biosphere Program in 1980. This region has a typical temperate continental monsoon climate. The northern slope of Changbai Mountain has a moderate slope $(<3 \%)$. With increasing altitude from 740 to 2,691 $\mathrm{m}$ above sea level, annual mean temperature changes from 3 to $-7^{\circ} \mathrm{C}$, and annual mean precipitation increases from 759 to $1,340 \mathrm{~mm}$ (He et al., 2005). The climatic variations along the northern slope form a clear vertical pattern of vegetation types, mirroring the latitudinal vegetation gradient from temperate to polar zones on the Eurasian continent.

Five typical vegetation types along the elevational gradient on the northern slope of Changbai Mt. were selected in this study: (i) Broad leaf-Korean pine mixed forest (BL-KP) $\left(42^{\circ} 23^{\prime}, 128^{\circ} 05^{\prime}\right)$ located between 740 and $1,100 \mathrm{~m}$ was dominated by a mixture of Korean pine (Pinus koraiensis) and broad leaf trees, including aspen (Populus davidiana Dode), birch (Betula platyphylla Suk), basswood (Tilia amurensis Rupr), oak (Quercus mongolica), maple (Acer mono Maxim), and elm (Ulmus pumila L.). The annual mean temperature (AMT) was $2.6^{\circ} \mathrm{C}$, and the annual mean precipitation (AMP) was $691 \mathrm{~mm}$, with soils classified as Albi-Boric Argosols according to the US Soil Taxonomy classification. (ii) Korean pine-Spruce fir forest community (KPSF) $\left(42^{\circ} 08^{\prime}, 128^{\circ} 07^{\prime}\right)$ located at $1,100-1,500 \mathrm{~m}$ was dominated by spruce (Picea jezoensis), fir (Abies nephrolepis), and Korean pine (Pinus koraiensis). The AMT was $0.3^{\circ} \mathrm{C}$, and the AMP was $811 \mathrm{~mm}$ with soils classified as Bori-Udic Cambosols. (iii) Spruce fir-Betula ermanii forest community (SF-BE) ranged from 1,500 to $1,800 \mathrm{~m}\left(42^{\circ} 04^{\prime}, 128^{\circ} 03^{\prime}\right)$, and the dominant tree species were spruce (Picea jezoensis) and fir (Abies nephrolepis), mixed with a few stands of Betula ermanii. The AMT was $-2.3^{\circ} \mathrm{C}$, and the AMP was $967 \mathrm{~mm}$. Soil was classified as Umbri-Gelic Cambosols. (iv) Betula ermanii forest (BE) $\left(42^{\circ} 03^{\prime}, 128^{\circ} 04^{\prime}\right)$ was located between 1,800 and $2,100 \mathrm{~m}$, and was dominated by Betula ermanii. The AMT was $-3.3^{\circ} \mathrm{C}$, and the AMP was $1,038 \mathrm{~mm}$. Soils were classified as Permi-Gelic Cambosols. (v) Alpine tundra (AT) $\left(42^{\circ} 02^{\prime}, 128^{\circ} 03^{\prime}\right)$ was located between 2,100 and 2,691 $\mathrm{m}$, and the dominant vegetation was Vaccinium vitis-idaea, Rhododendronaureum, Carex dispalata, and Dryas octopetala. The AMT was $-4.8^{\circ} \mathrm{C}$, and the AMP was $1,154 \mathrm{~mm}$. The soil was classified as Permafrost cold Cambisols (Xu et al., 2004; He et al., 2005; Shen et al., 2014).

\section{Soil Sample Collection and Analysis}

Soil samples were collected from six replicate plots $(20 \times 20 \mathrm{~m})$ adjacent to each other at each of the five vegetation types in early September 2014. To avoid the edge effect, all the soil samples were collected from the center of each vegetation zone, at least $50 \mathrm{~m}$ away from the upper and the lower boundary. The six replicate plots were evenly distributed within the center zone of each forest type. At each of the six experimental plots, five soil cores were randomly collected and mixed together to form a composite sample for the plot. Top soil $(0-10 \mathrm{~cm})$ of each soil core was collected using a $5 \mathrm{~cm}$ diameter PVC core soil sampler after the litter layer had been removed. Visible roots and residues were removed prior to homogenizing the soil cores. The composite samples were sieved at a mesh size of $2 \mathrm{~mm}$, and transported to the laboratory on ice within $48 \mathrm{~h}$ of sampling. The pooled soil samples were subdivided into three subsamples. The subsamples for determining soil physicochemical parameters were air-dried at ambient temperature until constant weight. For biological parameters, such as biomass and respiration, soils were stored at $4^{\circ} \mathrm{C}$, and subsamples for molecular analysis were kept at $-80^{\circ} \mathrm{C}$. 
The following soil characteristics were determined for each sample and used in the subsequent analyses: total carbon (TC), total nitrogen (TN), total sulfur (TS), $\mathrm{C} / \mathrm{N}$ ratio, nitrate- $\mathrm{N}\left(\mathrm{NO}_{3}^{-}\right.$$\mathrm{N})$, ammonium- $\mathrm{N}\left(\mathrm{NH}_{4}^{+}-\mathrm{N}\right)$, gravimetric moisture content, $\mathrm{pH}$, microbial biomass carbon (MBC), microbial biomass nitrogen $(\mathrm{MBN})$, basal respiration (BR), substrate induced respiration (SIR), and carbon availability index (CAI). Soil TC, TN, and TS were quantified using Elemental Analyzer (2400II CHN elemental analyzer; Perkin-Elmer, USA) after grinding by a Brinkmann Retsch mill (Haan, Germany). Soil $\mathrm{C} / \mathrm{N}$ ratio was calculated using TC and TN dataset. $\mathrm{NO}_{3}^{-}-\mathrm{N}$ and $\mathrm{NH}_{4}^{+}-\mathrm{N}$ were extracted in $2 \mathrm{M} \mathrm{KCl}$, and measured using a continuous-flow ion auto-analyzer (Scalar SANplus segmented flow analyzer, The Netherlands). Gravimetric soil moisture content was determined by drying overnight at $105^{\circ} \mathrm{C}$ and re-weighing to measure water loss. Soil pH was measured from a soil/water (1:2.5) suspension using PHS-3G digital pH meter (Precision and Scientific Crop, Shanghai, China). Soil MBC and MBN was measured using a chloroform fumigation extraction method (Brookes et al., 1985). Basal soil respiration (BR) was measured on soil samples that were incubated for $24 \mathrm{~h}$ in a closed vessel; headspace $\mathrm{CO}_{2}$ was measured using a Li-COR 8200 Infrared Gas Analyzer (IRGA) (Li-COR Biosciences, Lincoln, NB, USA). SIR was assayed as $\mathrm{CO}_{2}$ evolution within $2 \mathrm{~h}$ after glucose addition. CAI was calculated by dividing BR by SIR (Gershenson et al., 2009).

\section{DNA Extraction, Amplification and Sequencing}

Soil genomic DNA was extracted from $0.25 \mathrm{~g}$ of moist soil samples using a MoBio PowerSoil ${ }^{\circledR}$ DNA Isolation extraction kit (MoBio Laboratories Inc. Carlsbad, California, USA) following the manufacturer's instructions. The extracted DNA was quantified with a Nanodrop UV-Vis spectrophotometer (NanoDrop products, Wilmington, DE). The $\mathrm{V}_{1}-\mathrm{V}_{3}$ region of the bacterial 16S rRNA gene was amplified using the primers of 27F ( $5^{\prime}$-AGAGTTTGATCCTGGCTCAG-3') and 533R (5'TTACCGCGGCTGCTGGCAC-3') (Weisburg et al., 1991). The primers $1737 \mathrm{~F}\left(5^{\prime}\right.$-GGAAGTAAAAGTCGTAACAAGG-3') and 2043R (5'-GCTGCGTTCTTCATC GATGC-3') were used to amplify the fungal ITS region (Bellemain et al., 2010). Both forward and reverse primers were tagged with adapter, pad, linker, and 6 bp-barcode sequences. The 16S rRNA PCR reaction and amplification program were performed according to the protocols described in Li et al. (2016). Amplification of fungal ITS region was performed in triplicate in $20 \mu \mathrm{l}$ mixtures which contained $4 \mu \mathrm{l}$ of $5 \times$ FastPfu Buffer, $2 \mu \mathrm{l}$ of $2.5 \mathrm{mM}$ dNTPs, $0.8 \mu \mathrm{l}$ of each primer $(5 \mu \mathrm{M}), 0.4 \mu \mathrm{l}$ of FastPfu Polymerase, $0.2 \mu \mathrm{l}$ of BSA and $10 \mathrm{ng}$ of template DNA. The thermocycler conditions were: 35 cycles of $95^{\circ} \mathrm{C}$ for $30 \mathrm{~s}, 55^{\circ} \mathrm{C}$ for $30 \mathrm{~s}$ and $72^{\circ} \mathrm{C}$ for $45 \mathrm{~s}$, followed by a final extension at $72^{\circ} \mathrm{C}$ for $10 \mathrm{~min}$. The amplified 16S rRNA gene and ITS region were sequenced using 300PE (paired-end) and $250 \mathrm{PE}$ reads respectively, on the Illumina Miseq platform (Illumina, USA) at Majorbio Bio-Pharm Technology Co., Ltd., Shanghai, China.

Raw sequences files were demultiplexed, trimmed of reads containing ambiguous bases and long homopolymers, and merged using QIIME v 1.7.0 (Caporaso et al., 2012). Unique sequences were sorted by abundance, and singletons in the data set were discarded. All quality-filtered sequences from 16S rRNA and ITS gene amplicons were clustered into OTUs (Operational Taxonomic Unit) at 97\% similarity cutoff using UPARSE (version 7.1, http://drive5.com/uparse/), followed by chimera filtering using the Ribosomal Database Project (RDP) (Wang et al., 2007) and UCHIME (Edgar et al., 2011). To normalize all libraries to the same size, a subset of 8,000 sequences and 10,486 sequences per sample were randomly selected from bacterial 16S rRNA and fungal ITS datasets, respectively. Representative prokaryotic and fungal OTU sequences were classified taxonomically using the RDP classifier against Greengenes and UNITE reference databases, respectively. The census at each taxonomical level was processed with Perl scripts. The raw sequence data have been deposited in NCBI SRA under the accession number SRP061305.

\section{Identification of ECM and Saprotrophic Fungi}

The soil fungal community could be roughly divided into two ecological functional groups, represented by ECM and saprotrophic fungi (Leake et al., 2003; Read and Perez-Moreno, 2003; Kohler et al., 2015). We tried to identify genera that could be grouped either into ECM or into saprotrophic (or potential saprotrophic) fungi, based on previous published literature (Frankland, 1998; Tedersoo et al., 2010; Branco et al., 2013). ECM fungi generally fall within the phylum of Basidiomycota, and most of the saprotrophic fungi are phylogenetically classified as phylum Ascomycota (Table S1).

\section{Statistical Analysis}

$T$-test was used to assess the differences in soil properties and the relative abundance of dominant microbial taxa among different vegetation types. A Bonferroni correction was done for multiple comparisons ( $P$-value was corrected based on the number of comparisons). Soil variables and the relative abundance of microbial taxa which did not follow a normal distribution were ln-transformed.

Bray-Curtis distances of microbial community composition were computed using the vegan package in $\mathrm{R}$ (http://www.rproject.org/) based on OTU tables, and were then visualized using non-metric multidimensional scaling (NMDS) plots as implemented in PRIMER v6 (PRIMER-E, Ltd.). To determine whether vegetation type significantly influenced microbial community composition, permutational multivariate analysis of variance was performed using the ADONIS function implemented in the $\mathrm{R}$ statistical environment ( $\mathrm{v}$ 3.3.1), based on the Bray-Curtis dissimilarity matrix. To identify the relative importance of vegetation type and multiple soil variables contributing to the changes of microbial community composition, partial canonical correlation analysis (CCA) and subsequent Monte Carlo test (999 permutations) were performed using vegan package in R. Soil parameters used in CCA analysis were pre-selected by BIO-ENV function implemented in $\mathrm{R}$ vegan. Redundancy analysis (RDA) was performed with the software 
CANOCO 5.0 to further evaluate the relationships between soil microbial biomass, soil respiration parameters and selected microbial taxa.

Pearson's correlation was used to analyze the correlation between relative abundance of specific microbial taxa and soil properties by R “corrplot" package (version 3.3.1). Because of the non-independency of the replicates in this experimental design, a mixed model approach was used to analyze relationships between soil parameter and taxa relative abundances: Hierarchical Linear Models (HLM) were used to further explain the variation in the relative abundance of dominant microbial taxa using $\mathrm{R}$ "lme4" and "lmeTest" packages. Because of the collinearity among environmental factors, we pre-selected the parameters by removing variables with higher correlation $\left(r^{2}>0.6\right)$. Soil $\mathrm{pH}$, SIR, moisture, $\mathrm{NO}_{3}^{-}-\mathrm{N}, \mathrm{TN}, \mathrm{BR}, \mathrm{NH}_{4}^{+}-\mathrm{N}, \mathrm{C} / \mathrm{N}$ and CAI were selected as the individual-level variables in the HLM analysis. Vegetation type was considered the group-level variable. The best fitting models were selected based on the lowest AIC and BIC values.

\section{RESULTS}

\section{Soil Physico-Chemical Properties along the Elevational Gradients}

All soil physical and chemical properties measured in this study showed significant variations along the elevational gradient, except TC and TS (Table 1). The $\mathrm{C} / \mathrm{N}$ ratios in $\mathrm{BL}-\mathrm{KP}$ and $\mathrm{BE}$ forests, the two forests with more broad leaf trees, were much lower than the two dark-coniferous forests (KP-SF and SF-BE). Soil $\mathrm{NO}_{3}^{-}-\mathrm{N}$ and $\mathrm{NH}_{4}^{+}-\mathrm{N}$ showed the reverse pattern along the elevational gradient. Soil $\mathrm{NH}_{4}^{+}-\mathrm{N}$ concentrations showed a midelevation maximum pattern, with higher values being observed in the two dark-coniferous forests. In contrast, soil $\mathrm{NO}_{3}^{-}-\mathrm{N}$ concentrations was lowest at mid-elevation. The BL-KP forest located at the mountain foot and AT located at the summit contained more soil $\mathrm{NO}_{3}^{-}-\mathrm{N}$ than the other vegetation types. The highest soil moisture value was observed at the lowest altitude (BL-KP forest). Soil $\mathrm{pH}$ varied significantly $\left(t\right.$-test, $P_{\text {adjust }}<0.05$ ) across different vegetation types, ranging from 4.81 to 5.36 . In general, the $\mathrm{pH}$ values of $\mathrm{BL}-\mathrm{KP}, \mathrm{BE}$, and $\mathrm{AT}$ were higher than that of the two dark-coniferous forests.

The highest $\mathrm{MBC}$ and $\mathrm{MBN}$ were both observed in BL$\mathrm{KP}$ forest (Figures 1A,B), significant different with other forest types ( $t$-test, $\left.P_{\text {adjust }}<0.05\right)$. Soil basal respiration $(\mathrm{BR})$ was lowest at the KP-SF site, indicating the potential lower activity of soil organisms in this coniferous forest (Figure 1C). SIR, a key indicator of the activities of living biomass in soils, showed was lowest at mid-elevation (Figure 1D): The BL-KP, BE forest and AT exhibited higher SIR than the two dark coniferous forests. The carbon availability index (CAI), calculated by dividing the basal respiration rate by SIR rate, was significantly different $(t$ test, $P_{\text {adjust }}<0.05$ ) in the two dark-coniferous forest (ranging from 0.46 to 0.59 ) compared to the other locations (ranging from 0.25 to 0.35 ) (Figure 1E), largely driven by a decrease in SIR.

\section{Variations in the Overall Microbial Community Composition across Different Vegetation Types}

It was observed that the overall microbial community composition was significantly separated among different vegetation types, with respect to both bacterial (Figure 2A) and fungal (Figure 2B) communities (ADONIS, $P<0.01$ for both cases), indicating the significant contribution of vegetation type in shaping the soil microbial communities along this elevation transect. The pair-wise ADONIS analysis also revealed significant separation of microbial community composition between any of the two vegetation types (Table S2).

Partial CCA was used to identify the relative importance of vegetation types and soil parameters contributing to the variations in microbial community composition (Table 2). The largest proportion of the variation in bacterial community composition was explained by vegetation type $(15.13 \%, P<$ $0.05)$, followed by soil $\mathrm{pH}(3.78 \%), \mathrm{NO}_{3}^{-}-\mathrm{N}(3.26 \%)$, and $\mathrm{C} / \mathrm{N}$ ratio $(2.85 \%)(P<0.05$ for all soil variables). The community compositions of select bacterial phyla, Proteobacteria, Acidobacteria, Actinobacteria and Gemmatimonadetes, were also influenced significantly $(P<0.05$ for all cases) by the vegetation type. However, the composition of each of these dominant bacterial phyla was influenced by different soil parameters (Table 2). The total fungal community composition was only significantly influenced by vegetation type $(16.65 \%, P$ $<0.05)$. Phylum Basidiomycota was also influence by vegetation type $(16.40 \%, P<0.05)$, inferring the close relationship between this fungal population and the aboveground plants. Phylum Ascomycota, was significantly affected by both vegetation type $(19.25 \%, P<0.05)$ and multiple soil variables, including soil $\mathrm{C} / \mathrm{N}$ ratio, $\mathrm{NO}_{3}^{-}-\mathrm{N}$ concentrations and $\mathrm{pH}$.

\section{The Relative Abundances of Dominant Bacterial and Fungal Phyla along Elevational Gradients}

The dominant phyla accounting for more than $0.5 \%$ relative abundance in the overall bacterial communities were Proteobacteria (mean relative abundance across all sites of $43.31 \%)$, Acidobacteria (26.12\%), Actinobacteria (11.58\%), Planctomycetes (4.05\%), Verrucomicrobia (2.86\%), Bacteroidetes (2.70\%), Chloroflexi (2.37\%), Firmicutes $(0.85 \%)$ and Gemmatimonadetes (0.76\%) (Figure S1A). The relative abundances of Acidobacteria (Figure 3A) is significantly greater in the two dark-coniferous forests. The relative abundance of Actinobacteria (Figure 3D) was greatest in BL-KP forest and lowest in SF-BE forest, showing a roughly mid-elevational minimum distribution. Although no significant difference in the relative abundance of Proteobacteria was detected across different elevations, the lowest relative abundances were observed at mid-elevations (Figure 3B).

Basidiomycota and Ascomycota were the two most abundant phyla detected in fungal communities, accounting for $50.69 \%$ and $29.08 \%$ of the total fungal sequences, respectively (Figure S1B). Interestingly, these two phyla showed reverse distribution patterns along the elevational gradients. The relative abundances 
TABLE 1 | Soil properties along the northern slope of Changbai Mt.

\begin{tabular}{|c|c|c|c|c|c|c|c|c|c|}
\hline Vegetation & Elevation & $\begin{array}{c}\mathrm{TC}^{*} \\
\left(\mathrm{~g} \mathrm{~kg}^{-1}\right)\end{array}$ & $\begin{array}{c}\mathrm{TN} \\
\left(\mathrm{g} \mathrm{kg}^{-1}\right)\end{array}$ & $\begin{array}{c}\text { TS } \\
\left(\mathrm{g} \mathrm{kg}^{-1}\right)\end{array}$ & $\mathrm{C} / \mathrm{N}$ & $\begin{array}{c}\mathrm{NO}_{3}^{-}-\mathrm{N} \\
\left(\mathrm{mg} \mathrm{kg}^{-1}\right)\end{array}$ & $\begin{array}{c}\mathrm{NH}_{4}^{+}-\mathrm{N} \\
\left(\mathrm{mg} \mathrm{kg}^{-1}\right)\end{array}$ & $\begin{array}{c}\text { Moisture } \\
\text { (\%) }\end{array}$ & $\mathrm{pH}$ \\
\hline $\mathrm{BL}-\mathrm{KP}$ & $740-110 m$ & $\begin{array}{c}117.50 a^{\star *} \\
(14.72)\end{array}$ & $\begin{array}{l}9.56 a \\
(0.99)\end{array}$ & $\begin{array}{l}1.18 a \\
(0.17)\end{array}$ & $\begin{array}{c}12.22 \mathrm{c} \\
(0.46)\end{array}$ & $\begin{array}{l}9.86 a \\
(0.97)\end{array}$ & $\begin{array}{c}28.38 b \\
(4.89)\end{array}$ & $\begin{array}{l}0.36 a \\
(0.02)\end{array}$ & $\begin{array}{l}5.36 a \\
(0.06)\end{array}$ \\
\hline KP-SF & $1,100-1,500 \mathrm{~m}$ & $\begin{array}{c}101.95 a \\
(24.75)\end{array}$ & $\begin{array}{l}4.59 b \\
(0.95)\end{array}$ & $\begin{array}{l}0.83 a \\
(0.08)\end{array}$ & $\begin{array}{c}21.52 a \\
(1.01)\end{array}$ & $\begin{array}{l}4.60 b \\
(0.41)\end{array}$ & $\begin{array}{c}30.27 b \\
(5.17)\end{array}$ & $\begin{array}{l}0.25 b \\
(0.02)\end{array}$ & $\begin{array}{l}4.92 b \\
(0.10)\end{array}$ \\
\hline SF-BE & $1,500-1,800 \mathrm{~m}$ & $\begin{array}{c}100.12 \mathrm{a} \\
(8.42)\end{array}$ & $\begin{array}{c}6.51 \mathrm{ab} \\
(0.37)\end{array}$ & $\begin{array}{l}1.00 a \\
(0.06)\end{array}$ & $\begin{array}{c}15.29 b \\
(0.45)\end{array}$ & $\begin{array}{c}\text { 7.29ab } \\
(1.88)\end{array}$ & $\begin{array}{c}72.88 \mathrm{a} \\
(7.94)\end{array}$ & $\begin{array}{c}0.28 a b \\
(0.02)\end{array}$ & $\begin{array}{l}4.81 b \\
(0.04)\end{array}$ \\
\hline $\mathrm{BE}$ & $1,800-2,100 \mathrm{~m}$ & $\begin{array}{c}65.700 a \\
(10.18)\end{array}$ & $\begin{array}{l}5.29 b \\
(0.76)\end{array}$ & $\begin{array}{c}0.7 a \\
(0.06)\end{array}$ & $\begin{array}{c}12.38 c \\
(0.34)\end{array}$ & $\begin{array}{c}6.20 a b \\
(0.73)\end{array}$ & $\begin{array}{c}48.48 a b \\
(11.41)\end{array}$ & $\begin{array}{l}0.3 a b \\
(0.01)\end{array}$ & $\begin{array}{c}5.17 a b \\
(0.13)\end{array}$ \\
\hline AT & $2,100-2,691 \mathrm{~m}$ & $\begin{array}{c}109.85 a \\
(12.32)\end{array}$ & $\begin{array}{c}6.01 \mathrm{ab} \\
(0.56)\end{array}$ & $\begin{array}{l}0.84 a \\
(0.06)\end{array}$ & $\begin{array}{c}18.27 \mathrm{ab} \\
(0.97)\end{array}$ & $\begin{array}{c}15.0 \mathrm{ab} \\
(5.93)\end{array}$ & $\begin{array}{c}28.79 b \\
(8.58)\end{array}$ & $\begin{array}{l}0.3 a b \\
(0.02)\end{array}$ & $\begin{array}{l}5.2 a b \\
(0.14)\end{array}$ \\
\hline
\end{tabular}

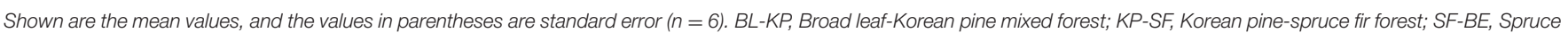
Fir-Betula ermanii forest; BE, Betula ermanii forest; AT, Alpine tundra.

${ }^{\star} T C$, total carbon; TN, total nitrogen; TS, total sulfur; $C / N$, carbon:nitrogen ratio.

${ }^{*}$ Different letters indicate significant differences ( $t$-test, $\left.P_{\text {adjust }}<0.05\right)$ among vegetation types.

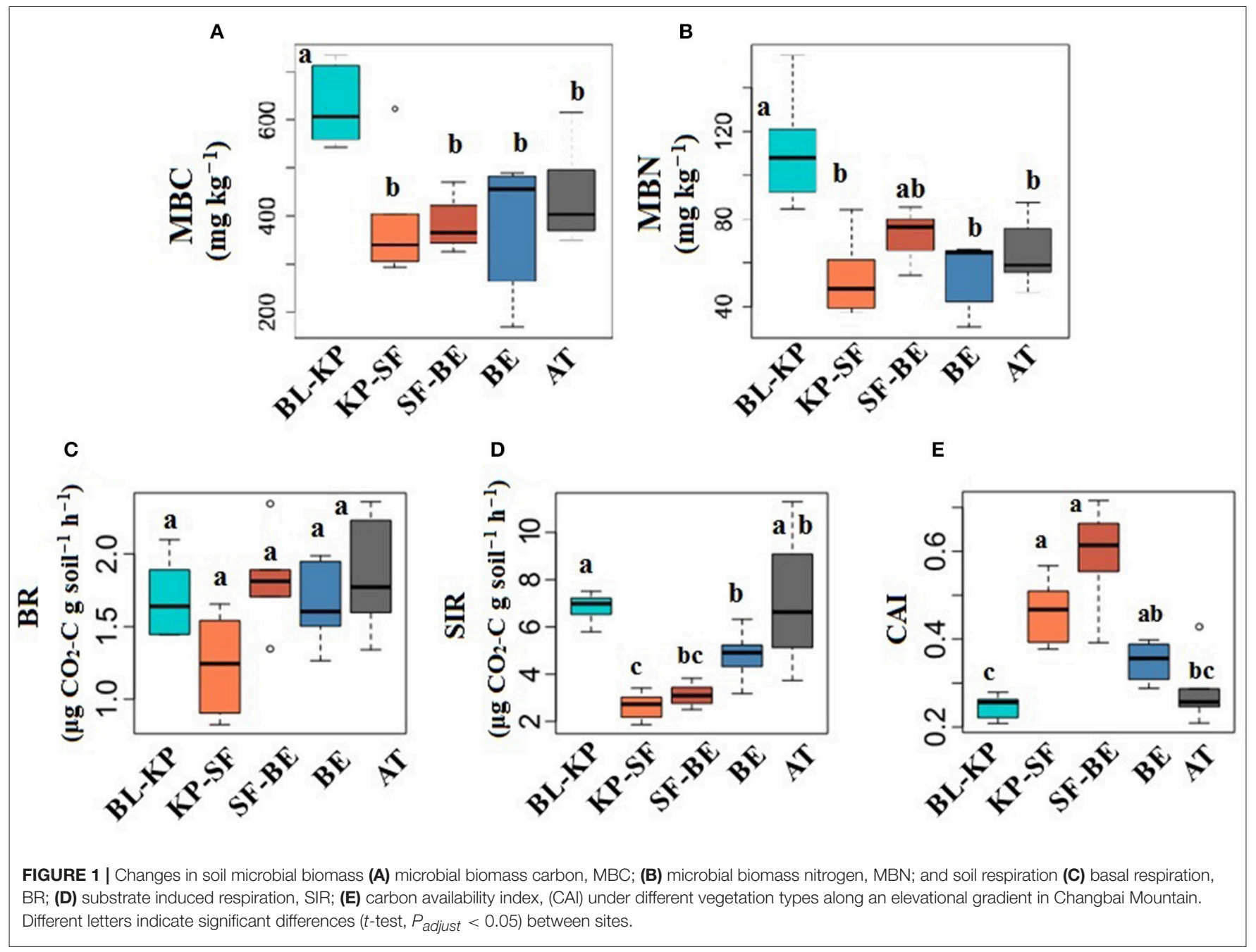




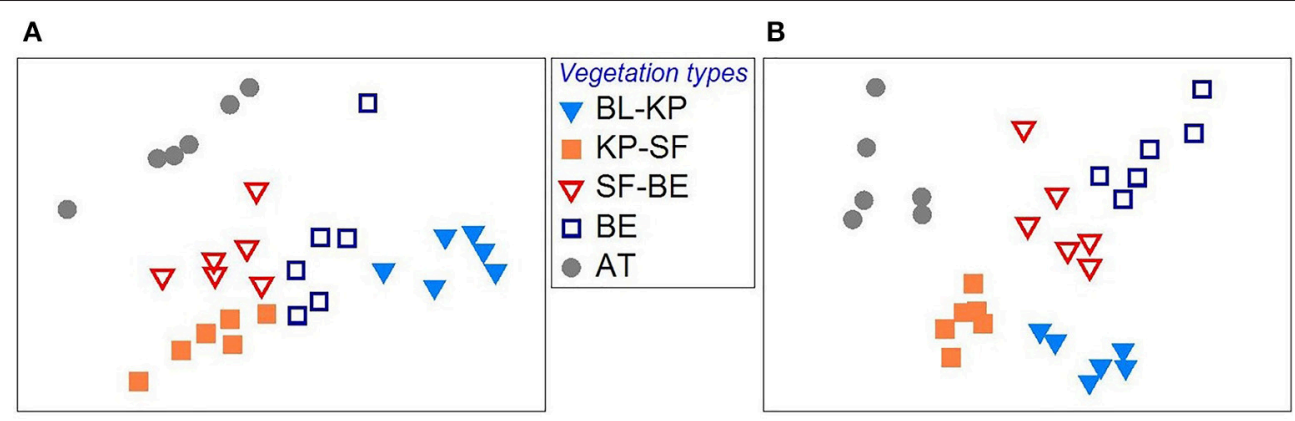

FIGURE 2 | The variation in bacterial (A) and fungal (B) community composition across the elevational gradient on Changbai Mt., as revealed by Non Metric Multidimensional Scaling (NMDS) plot based on Bray-Curtis distances. BL-KP, Broad leaf-Korean pine mixed forest; KP-SF, Korean pine-spruce fir forest; SF-BE, Spruce Fir-Betula ermanii forest; BE, Betula ermanii forest; AT, Alpine tundra.

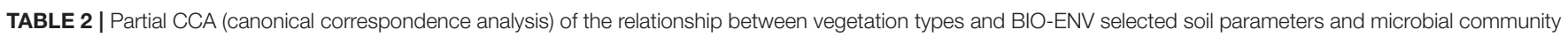
composition.

\begin{tabular}{|c|c|c|c|c|c|c|c|c|}
\hline & & Vegetation types & $\mathrm{NO}_{3}^{-}-\mathrm{N}$ & $\mathrm{C} / \mathrm{N}$ & MBN & SIR & CAl & $\mathrm{pH}$ \\
\hline \multirow[t]{3}{*}{ Bacteria } & Contribution & $15.13 \%$ & $3.26 \%$ & $2.85 \%$ & $2.11 \%$ & $2.24 \%$ & $2.00 \%$ & $3.78 \%$ \\
\hline & $\mathrm{F}$ & 1.920 & 1.666 & 1.446 & 1.070 & 1.136 & 1.017 & 1.920 \\
\hline & $P$ & 0.001 & 0.007 & 0.034 & 0.345 & 0.245 & 0.455 & 0.003 \\
\hline \multirow[t]{3}{*}{ Proteobacteria } & Contribution & $15.85 \%$ & $3.56 \%$ & $3.04 \%$ & $1.86 \%$ & $2.31 \%$ & $2.10 \%$ & $3.29 \%$ \\
\hline & $\mathrm{F}$ & 2.316 & 2.080 & 1.777 & 1.086 & 1.348 & 1.226 & 1.920 \\
\hline & $P$ & 0.001 & 0.002 & 0.013 & 0.341 & 0.088 & 0.173 & 0.008 \\
\hline \multirow[t]{3}{*}{ Actinobacteria } & Contribution & $14.71 \%$ & $2.54 \%$ & $2.48 \%$ & 1.927 & $1.64 \%$ & $1.72 \%$ & $4.80 \%$ \\
\hline & $\mathrm{F}$ & 2.088 & 1.430 & 1.417 & 1.094 & 0.931 & 0.975 & 2.726 \\
\hline & $P$ & 0.001 & 0.11 & 0.091 & 0.283 & 0.467 & 0.443 & 0.004 \\
\hline \multirow[t]{3}{*}{ Acidobacteria } & Contribution & $15.8 \%$ & $2.63 \%$ & $2.54 \%$ & $2.05 \%$ & $1.85 \%$ & $1.72 \%$ & $3.73 \%$ \\
\hline & $\mathrm{F}$ & 2.291 & 1.524 & 1.473 & 1.186 & 1.074 & 0.996 & 2.165 \\
\hline & $P$ & 0.001 & 0.022 & 0.044 & 0.21 & 0.341 & 0.446 & 0.001 \\
\hline \multirow[t]{3}{*}{ Gemmatimonadetes } & Contribution & $17.50 \%$ & $3.86 \%$ & $2.91 \%$ & $2.94 \%$ & $2.84 \%$ & $2.15 \%$ & $4.61 \%$ \\
\hline & $\mathrm{F}$ & 1.874 & 1.654 & 1.247 & 1.259 & 1.217 & 0.922 & 1.980 \\
\hline & $P$ & 0.001 & 0.018 & 0.141 & 0.121 & 0.177 & 0.568 & 0.006 \\
\hline \multirow[t]{3}{*}{ Fungi } & Contribution & $16.65 \%$ & $3.89 \%$ & $3.41 \%$ & $2.81 \%$ & $3.61 \%$ & $3.62 \%$ & $3.32 \%$ \\
\hline & $\mathrm{F}$ & 1.425 & 1.332 & 1.167 & 0.961 & 1.234 & 1.240 & 1.135 \\
\hline & $P$ & 0.001 & 0.065 & 0.231 & 0.553 & 0.158 & 0.142 & 0.28 \\
\hline \multirow[t]{3}{*}{ Basidiomycota } & Contribution & $16.4 \%$ & $3.71 \%$ & $3.23 \%$ & $3.17 \%$ & $3.12 \%$ & $3.58 \%$ & $3.28 \%$ \\
\hline & $\mathrm{F}$ & 1.344 & 1.212 & 1.057 & 1.038 & 1.021 & 1.171 & 1.074 \\
\hline & $P$ & 0.002 & 0.17 & 0.428 & 0.433 & 0.468 & 0.237 & 0.375 \\
\hline \multirow[t]{3}{*}{ Ascomycota } & Contribution & $19.25 \%$ & $5.18 \%$ & $4.83 \%$ & $2.68 \%$ & $4.02 \%$ & $2.56 \%$ & $3.69 \%$ \\
\hline & $\mathrm{F}$ & 2.074 & 2.233 & 2.080 & 1.156 & 1.734 & 1.103 & 1.589 \\
\hline & $P$ & 0.001 & 0.003 & 0.014 & 0.332 & 0.027 & 0.398 & 0.036 \\
\hline
\end{tabular}

Bold values indicate that the correlations are significant $(P<0.05$, Monte Carlo test of significance).

of Basidiomycota were greater in the two dark-coniferous forests (Figure 3E), whereas the relative abundance of Ascomycota (Figure 3F) was significantly greater at the lowest and highest elevation sites (BL-KP and AT).

\section{The Relative Abundance of Specific Microbial Classes along Elevational Gradients}

The Alphaproteobacteria and Betaproteobacteria were the most two abundant Proteobacterial classes across all soil samples, accounting for 81.66 and $6.28 \%$ of all Proteobacteria sequences, respectively. The relative abundances of these two Proteobacterial classes were much lower in the two darkconiferous forests (Figures 4C,D), consistent with the pattern for total Proteobacteria. In contrast, the less predominant classes Deltaproteobacteria and Gammaproteobacteria (represented 3.36 and $5.99 \%$ of all Proteobacterial sequences) generally exhibited an opposite pattern (Figures 4A,B), with higher proportions in the two dark-coniferous forests. AT also had similarly higher proportions of Gamma- and Delta-Proteobacteria to the dark coniferous sites. 

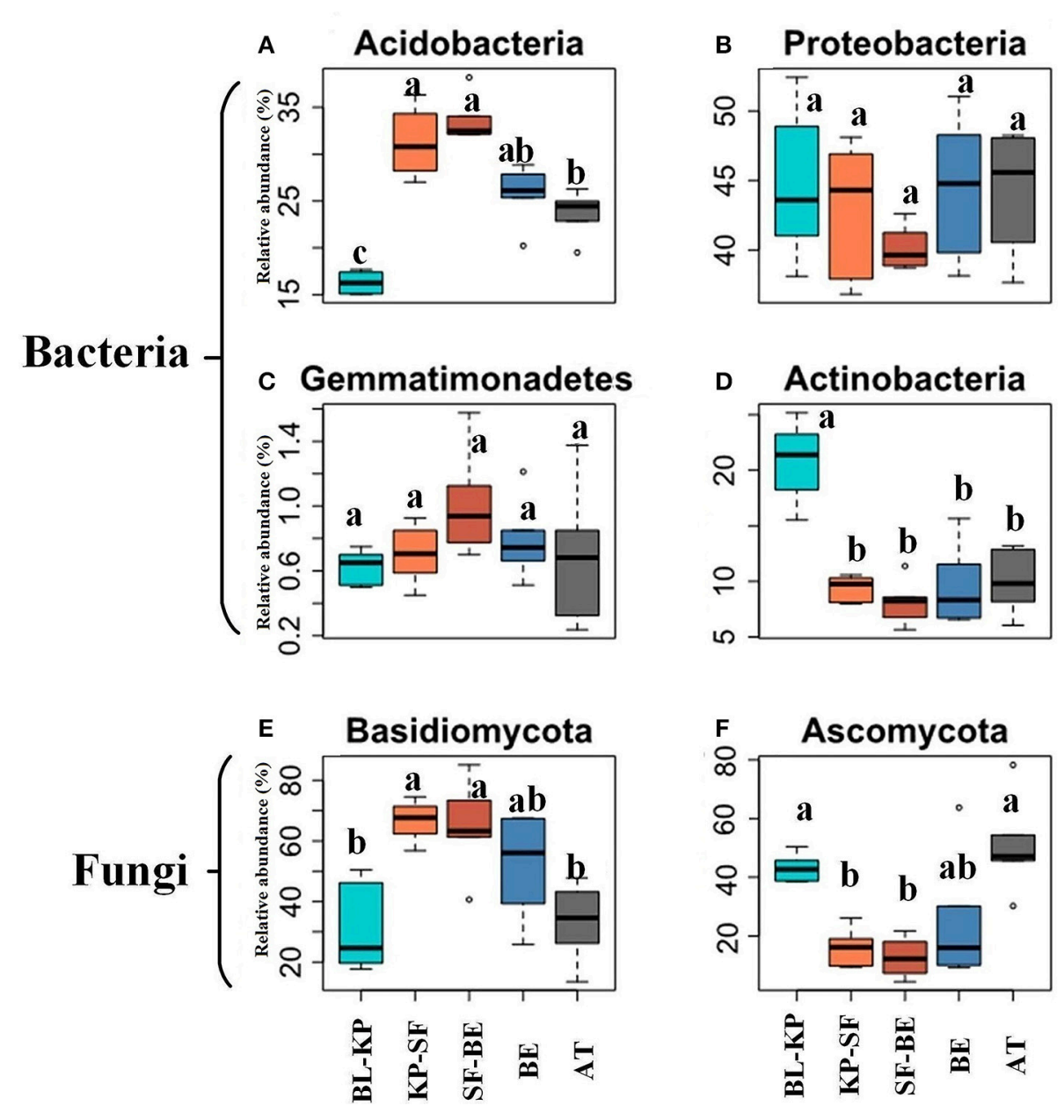

FIGURE 3 | The relative abundances of selected bacterial and fungal phyla along the elevational gradients. The bacterial phyla of Acidobacteria (A) and Gemmatimonadetes (C), and fungal phylum of Basidiomycota (E) demonstrated highest relative abundances at mid-elevation, whereas the bacterial phyla of Proteobacteria (B) and Actinobacteria (D), and fungal phylum of Ascomycota (F) showed lowest relative abundances at mid elevation (right panel). Significant differences ( $t$-test, $P_{\text {adjust }}<0.05$ ) among vegetation types are marked by different letters. BL-KP, Broad leaf-Korean pine mixed forest; KP-SF, Korean pine-spruce fir forest; SF-BE, Spruce Fir-Betula ermanii forest; BE, Betula ermanii forest; AT, Alpine tundra.

In this experiment, 16 sub-groups of Acidobacteria were detected, including Gp1 (accounted for 46.73\% of all Acidobacteria sequences), Gp2 (16.84\%), Gp3 (25.27\%), Gp4 (1.79\%), Gp5 (0.54\%), Gp6 (2.46\%), Gp7 (1.14\%), Gp10 (0.04\%), Gp11 (0.15\%), Gp12 (0.08\%), Gp13 (0.08\%), Gp15 (0.09\%), Gp16 (3.48\%), Gp17 (0.10\%), Gp22 (0.005\%), and Gp25 (0.02\%). However, not all subgroups showed a similar distribution pattern along the elevational gradient. The relative abundances of subgroups Gp1, Gp2, Gp3, and Gp15 were much higher in the two dark-coniferous forests than the other vegetation types, showing a general mid-elevational maximum pattern (Figures 4E,F,I,J). In contrast, subgroups Gp4, Gp6, Gp7, and Gp16 were relatively more abundant in forests with broad leaf trees and AT, exhibiting a mid-elevational minimum pattern (Figures 4G,H,K,L).

Basidiomycota and Ascomycota are the two predominant fungal phyla detected in this study, and more intensive analyses were conducted on these two fungal phyla to examine the patterns of specific fungal classes. We found that the most predominant class in Basidiomycota, Agaricomycetes (which accounted for $88.16 \%$ of the total Basidiomycotal sequences), followed the same elevational pattern (Figure 5A) with the phylum of Basidiomycota, with highest relative abundances at mid-elevation. Though it was not statistically significant, the class of Wallemiomycetes (1.05\%) also showed a slight oligotrophic trend (Figure 5D), with the highest abundance being detected at KP-SF forest. However, another Basidiomycotal class, Tremellomycetes (5.97\%), showed a reverse pattern (Figure 5F). The elevational distribution patterns of the Ascomycotal classes, Leotiomycetes (accounted for $42.51 \%$ of the total Ascomycotal sequences), Dothideomycetes (15.70\%), and Eurotiomycetes (5.53\%), were all in line with phylum Ascomycota, exhibiting a mid-elevational minimum pattern (Figures 5B,C,E). The Microbotryomycetes in Basidiomycota 


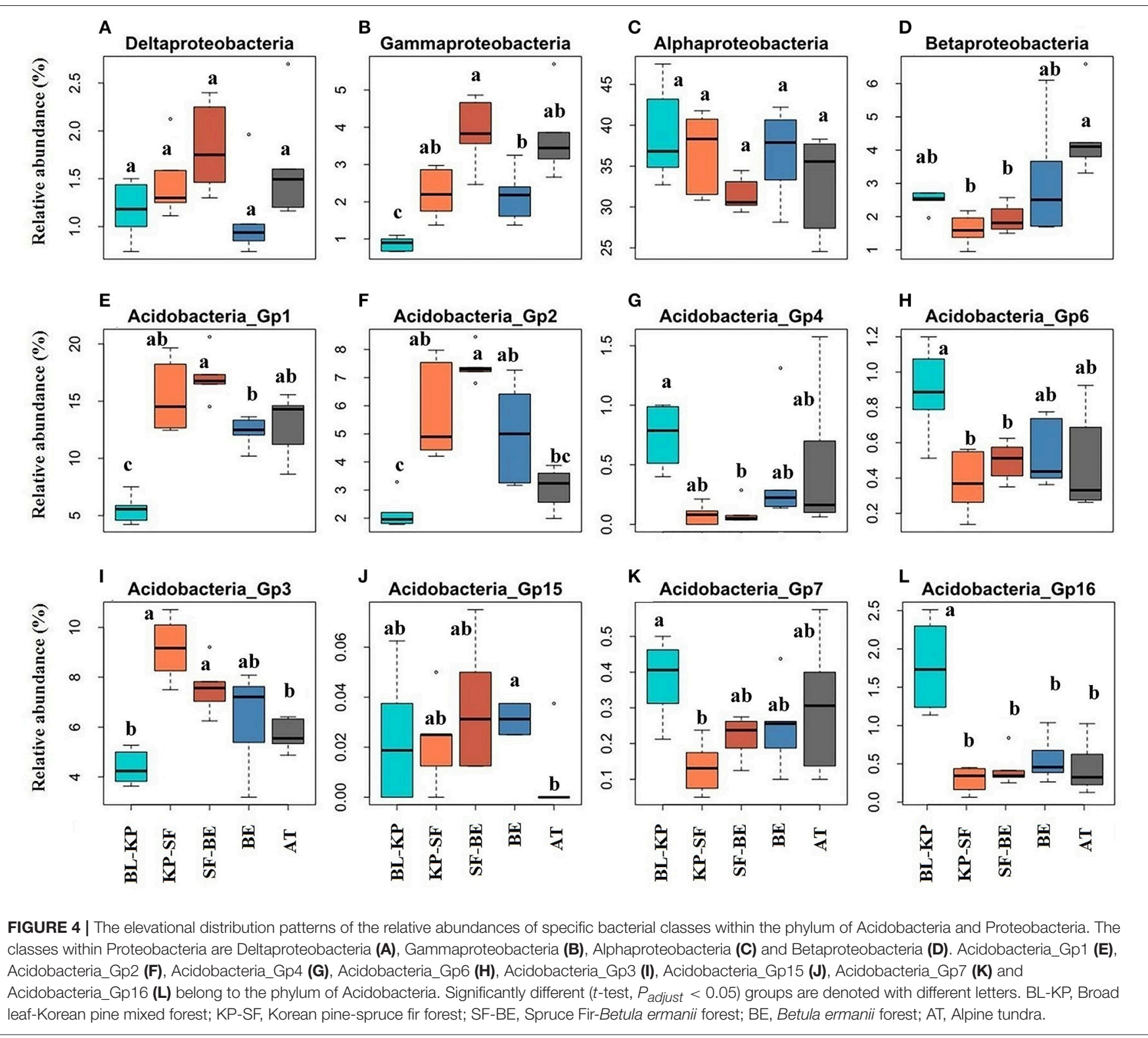

and the Sordariomycetes in Ascomycota both showed nonsignificant elevational patterns along the mountain slope.

\section{Distribution Pattern of the Relative Abundances of ECM and Saprotrophic Fungi along the Mountain Slope}

To elucidate if the taxonomic distribution patterns of fungal communities were associated with their potential specific function, we further investigated the elevational patterns of the two predefined functional groups, ectomycorrhizal (ECM) and saprotrophic fungi. The relative abundances of ECM and saprotrophic fungi were summarized by artificially screening sequences that are phylogenetically associated with the previously identified ECM and saprotrophic fungal genera. A total of 41 ECM fungal genera were selected in this study, including 27 Basidiomycotal genera and 14 Ascomycotal genera (Table
S1). Within the 41 genera of ECM fungi, $98.03 \%$ of the sequences belonged to phylum Basidiomycota. Consequently, the elevational pattern of the relative abundance of ECM fungi was in line with the pattern of Basidiomycota (Figure 3E), with highest abundances at mid-elevation (Figure 6A).

A total of 16 saprotrophic (or potential saprotrophic) fungal genera were selected, including 13 Ascomycotal genera, 2 Basidiomycotal genera, and 1 Zygomycotal genus. Of the total 2,211 selected saprotrophic fungal sequences, 346 sequences were phylogenetically associated with Ascomycota (accounting for $15.65 \%$ of all saprotrophic fungal sequences), and 263 sequences associated with Basidiomycota (11.90\%). Though only one genus, Mortierella, was selected from Zygomycota, a large proportion $(74.85 \%)$ of the selected saprotrophic fungal sequences were associated with this genus. The relative abundances of saprotrophic fungi in KP-SF forest was much 

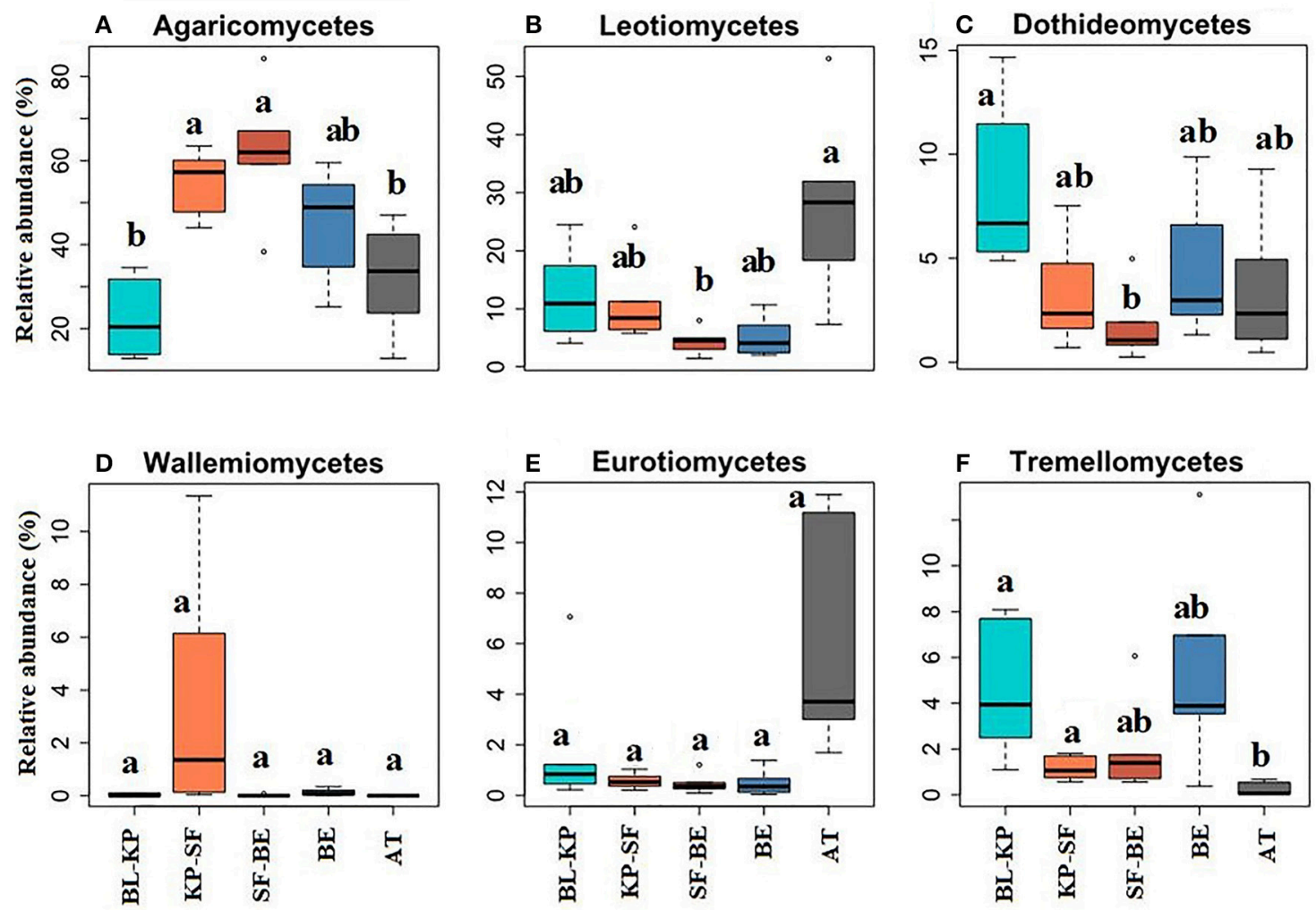

FIGURE 5 | The elevational distribution patterns of the relative abundances of specific fungal classes within the phylum of Basidiomycota and Ascomycota. Agaricomycetes (A) and Wallemiomycetes (D) belong to Basidiomycota, Leotiomycetes (B), Dothideomycetes (C), Eurotiomycetes (E), and Tremellomycetes (F) are classes within Ascomycota. Significantly different ( $t$-test, $P_{\text {adjust }}<0.05$ ) groups are denoted with different letters. BL-KP, Broad leaf-Korean pine mixed forest; KP-SF, Korean pine-spruce fir forest; SF-BE, Spruce Fir-Betula ermanii forest; BE, Betula ermanii forest; AT, Alpine tundra.
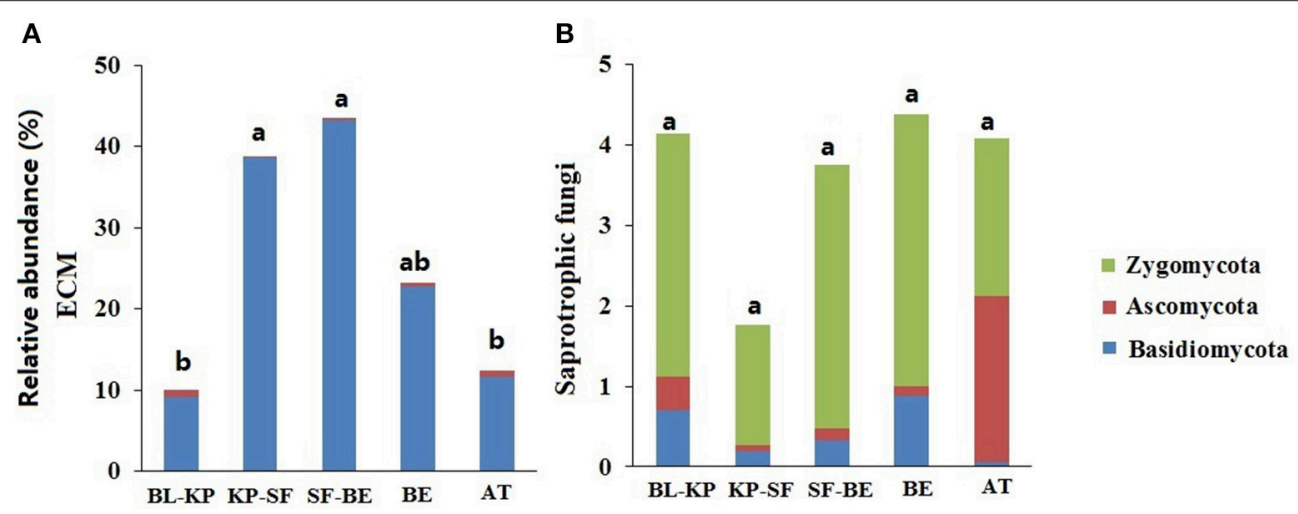

FIGURE 6 | The elevational distribution patterns of the mean relative abundance of two fungal functional groups: ECM (A) and saprotrophic fungi (B), and their phylogenetic affiliation. Significantly different $\left(t\right.$-test, $\left.P_{\text {adjust }}<0.05\right)$ groups are denoted with different letters.

lower than the other vegetation types (Figure 6B), exhibiting a pattern consistent with that of Ascomycota (Figure 3F). The proportions of Ascomycotal saprotrophic fungi were much higher in BL-KP and AT, whereas the Basidiomycotal saprotrophic fungi represented only a small percentage of the total saprotrophic fungi in AT ecosystem.

\section{Correlations between the Relative Abundances of Dominant Taxa and Soil Properties}

We performed correlation analysis to examine the relationships between the relative abundances of different bacterial and 


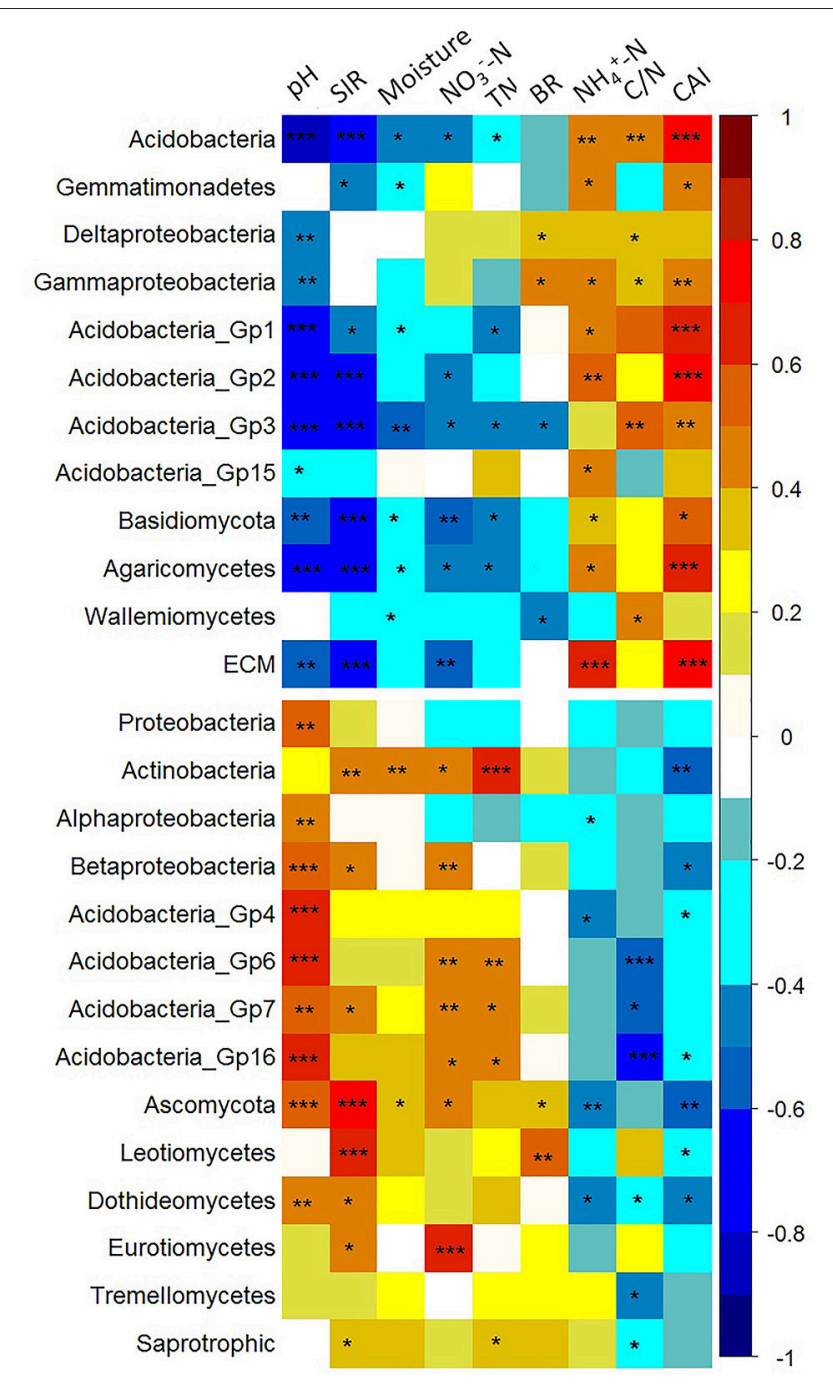

FIGURE 7 | Pearson's correlation coefficients between the relative abundances of specific microbial taxa and the selected soil properties. The correlation coefficients ranging from negative to positive are indicated by color intensity changing from dark blue to red, as illustrated by the figure legend. In general, it was shown that the relative abundances of the so-called "oligotrophic" microbial groups (located at the upper panel) showed positive correlations with $\mathrm{NH}_{4}^{+}-\mathrm{N}, \mathrm{C} / \mathrm{N}$ and $\mathrm{CAl}$ (covered by orange to red color), but negative correlations with $\mathrm{TN}, \mathrm{NO}_{3}^{-}-\mathrm{N}$, moisture content, $\mathrm{SIR}$ and $\mathrm{pH}$ (covered by cyan and blue color). In contrast, the relative abundances of the "copiotrophic" members (the lower panel) demonstrated the reverse patterns. ${ }^{*} 0.01<P<0.05,{ }^{* *} 0.001<P<0.01,{ }^{* \star *} P<0.001$.

fungal taxa and selected soil properties. The calculated Pearson correlation coefficients between the relative abundances of specific microbial taxa and the measured soil properties are shown in Table S3, and indicated by color intensity in Figure 7. For the bacterial community, the relative abundances of Acidobacteria and Gemmatimonadetes, classes of Gammaand Delta-Proteobacteria, and Acidobacteria_Gp1, Gp3, Gp5, Gp15 showed general positive correlations with $\mathrm{NH}_{4}^{+}-\mathrm{N}, \mathrm{C} / \mathrm{N}$, and $\mathrm{CAI}$, but negative correlations with $\mathrm{TN}, \mathrm{NO}_{3}^{-}-\mathrm{N}$, moisture content, SIR, and $\mathrm{pH}$. In contrast, the relative abundances of the phylum of Actinobacteria, classes of Betaproteobacteria, and Acidobacteria_Gp4, Gp6, Gp7, and Gp16 showed a reverse pattern, being negatively correlated with $\mathrm{NH}_{4}^{+}-\mathrm{N}, \mathrm{C} / \mathrm{N}$, and CAI. The proportion of the overall Proteobacteria was positively correlated with soil $\mathrm{pH}(P<0.05)$. As for the fungal community, the relative abundances of Basidiomycota, class of Agaricomycetes and ECM fungi were positively correlated with CAI $(P<0.05)$, but negatively correlated with $\mathrm{TN}, \mathrm{NO}_{3}^{-}-\mathrm{N}$, moisture content, SIR and $\mathrm{pH}$, whereas those of Ascomycota, classes of Leotiomycetes, Dothideomycetes, Eurotiomycetes, and Tremellomycetes, and saprotrophic fungi illustrated an opposite pattern. In summary, it was found that the microbial taxa with higher relative abundances at mid-elevation generally showed positive correlations with $\mathrm{NH}_{4}^{+}-\mathrm{N}, \mathrm{C} / \mathrm{N}, \mathrm{CAI}$ and negative correlations with $\mathrm{TN}, \mathrm{NO}_{3}^{-}-\mathrm{N}$, moisture content, SIR and $\mathrm{pH}$. The redundancy analysis (RDA) based on the relative abundance of selected microbial taxa revealed that the soil microbial biomass, BR and SIR were positively correlated with the copiotrophic microbial taxa (Figure S2). The results of HLM also indicated that $\mathrm{pH}, \mathrm{TN}, \mathrm{SIR}$, and CAI could explain the variation in the relative abundance of selected taxa (Table S4). This was in line with the Pearson's correlation analysis which showed that the relative abundance of almost all copiotrophic taxa increased with increasing $\mathrm{pH}$ and $\mathrm{TN}$. In contrast to the copiotrophic taxa, $\mathrm{pH}$ and $\mathrm{TN}$ shows negative relationship with oligotrophic taxa (Table S4).

\section{DISCUSSION}

\section{Ecological Classification of Oligotrophic and Copiotrophic Microbial Taxa}

The mechanisms and theory explaining elevational patterns of soil microbial alpha-diversity have been frequently proposed. For example, soil $\mathrm{pH}$ is often suggested as the key factor driving elevational alpha-diversity patterns of soil microbes (Bryant et al., 2008; Singh et al., 2012; Shen et al., 2013; Wang J. T. et al., 2015; Zhang et al., 2015). Moreover, the elevational pattern of bacterial alpha-diversity was also suggested to be influenced by aboveground vegetation diversity (Zhang et al., 2015). The fungal beta-diversity has been proposed to be mainly related to soil organic matter (Zinger et al., 2011). However, the mechanisms driving the distribution pattern of the relative abundance of specific microbial taxa along mountain slopes is still not well-understood. In this study, we described the composition of bacterial and fungal communities along the northern slope of Changbai Mountain and used a oligotrophiccopiotrophic theory to explain the elevational distribution pattern of the relative abundance of dominant soil microbial taxa.

Consistent with our initial hypothesis, different vegetation types across elevational gradients harbored distinct soil bacterial and fungal communities. In particular, the well-defined oligotrophic bacterial phylum, Acidobacteria (Smit et al., 2001; Ramirez et al., 2010, 2012; Fierer et al., 2012; Li et al., 2014, 2016; Pan et al., 2014), had a greater relative abundance in the two dark-coniferous forests at mid-elevation, habitats which were relatively nutrient-poor compared to the other sites. In contrast, Proteobacteria, which is generally considered to be copiotrophic 
(Fierer et al., 2007; Francioli et al., 2016), did not change in relative abundances across the elevation gradient.

There is an enormous amount of phylogenetic and physiological diversity within each phylum, and it is unlikely that an entire phylum would share common ecological characteristics. Thus, we further examined taxa distributions at finer taxomomic levels within the phyla of Acidobacteria and Proteobacteria. In the phylum of Proteobacteria, it is generally accepted that the Alpha- and Beta-Proteobacteria are copiotrophic members (Fierer et al., 2007; Zhao et al., 2014), because they are usually associated with habitats having relatively low soil $\mathrm{C} / \mathrm{N}$ ratio, high $\mathrm{NO}_{3}^{-}-\mathrm{N}$ (Nugroho et al., 2005), and enriched nutrients (Leff et al., 2015; Li et al., 2016). The ecological classification of Gammaproteobacteria is less clear (Cho and Giovannoni, 2004; Cleveland et al., 2007; Fierer et al., 2007; Leff et al., 2015). Deltaproteobacteria is typically classified into the oligotrophic group, as revealed by the relatively low abundances in nutrient rich habitats (Banning et al., 2011). Our results are generally consistent with previous ecological classification of proteobacterial classes, with Alpha- and Beta-Proteobacteria having the highest relative abundances at the nutrient rich sites and Gamma- and Delta-having the highest relative abundance in the nutrient-poor dark-coniferous sites.

The present study showed that within the phylum of Acidobacteria, the subgroups of Acidobacteria_Gp1, Gp2, Gp3, Gp15 had a higher relative abundance in the two darkconiferous forests. In contrast, members of Gp4, Gp6, Gp7, and Gp16 had higher relative abundances in forests with broad leaf trees. Our results are in line with a variety of previous studies. For example, it was documented that Gp1 and Gp3 were more abundant in bulk soil (defined as a low-nutrient habitat) than in the rhizosphere soil (a typical nutrient-rich niche), whereas Gp6 showed the potential predominance in the rhizosphere soil (Nunes da Rocha et al., 2013). A study on forest-to-pasture conversion found that Acidobacteria subgroups Gp1, 3, 5, 9, 11, and 13 were significantly associated with forest soils and were negatively correlated with soil nutrients contents, while subgroups $4,6,7,10,17,18$, and 25 were associated with pasture soils, and were positively correlated to nutrient availability (Navarrete et al., 2015). There is also genetic evidence supporting our classification of Gp1 and Gp3 subdivisions into oligotrophic categories: Genome analysis of representative $\mathrm{Gp} 1$ and $\mathrm{Gp} 3$ strains revealed that their genomes encode low-specificity major facilitator super family transporters and high-affinity $\mathrm{ABC}$ transporters for sugars, suggesting a suitability to low-nutrient conditions (Ward et al., 2009).

Examining the distributions of other abundant bacterial phyla provided some insight into their trophic categories. For example, the relative abundance of Gemmatimonadetes was much higher in the two dark-coniferous forests, implying oligotrophic tendencies. Gemmatimonadetes has also been proposed as oligotrophic taxa based on other studies, evidenced by a decline in relative abundance under $\mathrm{N}$ enrichment (Zhang et al., 2003; Cederlund et al., 2014), and an increase in absolute abundances in dryer soils (DeBruyn et al., 2011). In addition, cultivated Gemmatimonadetes strains grow like oligotrophs, preferring minimal media and exhibiting slow growth rates
(DeBruyn et al., 2013). Thus, the relatively low soil moisture and high $\mathrm{C} / \mathrm{N}$ ratios in the coniferous forests likely contributed to the increased relative abundance of Gemmatimonadetes at those sites.

The ecological category of Actinobacteria has not been clearly defined, with previous studies reporting mixed results in response to nutrient additions (Fierer et al., 2012; Ramirez et al., 2012; Zhao et al., 2014; Leff et al., 2015; Li et al., 2016). Actinobacteria were long believed to behave like fungi, growing slowly and thus behaving like oligotrophs. However, they also play important roles in decomposing the soil organic matter (Dignac et al., 2005), which may imply copiotrophic tendencies. In this study, it was observed that the relative abundance of Actinobacteria was highest in the BL-KP forest, and lower in the two darkconiferous forests, suggesting a copiotrophic tendency. The inability to definitively classify the entire phyla is likely due the diverse morphological and metabolic repertoires of different Actinobacteria (Embley and Stackebrandt, 1994; Boone and Castenholz, 2001; Garrity and Holt, 2001).

Though the oligotrophic-copiotrophic theory has been intensively discussed within the domain of bacteria, it is less often applied to soil fungal taxa. The Basidiomycota and Ascomycota are two commonly reported soil fungal phyla in forest soils (Frankland, 1998; McGuire et al., 2013). Interestingly, we observed the opposite distribution patterns of these two fungal phyla along the mountain slope. Basidiomycota had the highest relative abundances at the dark forest sites, similar to the oligotrophic bacteria, whereas Ascomycota had the highest relative abundances at the nutrient rich sites, consistent with bacterial copiotrophs. The phenotypic and phylotypic differences between ECM (which are mainly Basidiomycetes) and saprotrophic fungi (which are mainly Ascoymcetes) may support our classification of Basidiomycota and Ascomycota into the oligotrophic and copiotrophic categories, respectively. Overall, mycorrhizal and saprotrophic fungi are likely to be spatially segregated and play fundamentally different roles in the ecosystem. ECM fungi are known to be oligotrophic, and are usually more abundant in deeper soil depths with fragmented litter and humus (Lindahl et al., 2007; McGuire et al., 2013). In contrast, saprotrophic fungi usually exhibit copiotrophic tendencies because they are more efficient in utilizing fresh, energy-rich litter (Lindahl et al., 2007; Crowther et al., 2012) and colonizing nutrient-rich habitats, such as the surface of the forest floor (Lindahl et al., 2007; Lievens et al., 2015). Moreover, previous studies suggested that increasing $\mathrm{N}$ supply generally reduced the relative abundances of mycorrhizal fungi (Högberg et al., 2003; Treseder, 2004), such as the Basidiomycetes Cortinarius and Russula (Lilleskov et al., 2001), but increased the biomass of saprotrophic fungi (Högberg et al., 2003). The different response of ECM and saprotrophic fungi to $\mathrm{N}$ enrichment may rely on the opposing nutrient limitations governing C-supply. Specifically, increased $\mathrm{N}$-supply reduces $\mathrm{C}$ supply to plant roots and their mycorrhizal symbionts, while saprotrophic fungi enhance the C-supply due to increased plantbiomass (Högberg et al., 2003). A recent study of genomes of selected mycorrhizal and saprotrophic fungi strains found that ectomycorrhizal fungi have a reduced complement of genes encoding plant cell wall-degrading enzymes, but a rapid 
genetic turnover in symbiosis-induced genes, compared to their saprotrophic precursors. The convergent losses of ancestral saprotrophic components lower the decomposition ability of ECM fungi (Kohler et al., 2015). Nevertheless, interpretation of ECM fungi data in this study is limited, because ITS sequencing of bulk soil is unlikely to capture the whole profile of ECM fungi (Dickie et al., 2002). Morphological identification is still essential to identify ECM (Smith and Read, 2008), and further ultrastructural or morphological characterization in combination with DNA-based methods would be needed for obtaining a more comprehensive ECM community profile.

The classes within the fungal phylum of Basidiomycota had different distributions, with Agaricomycetes showing an oligotrophic trend and Tremellomycetes demonstrating a copiotrophic tendency. It was suggested that the loss of aggressive ligninolysis in Agaricomycetes has occured in the evolution toward biotrophic ectomycorrhiza (Eastwood et al., 2011), and thus they behave as oligotrophs. Moreover, previous research has shown that Cortinarius and Russula Agaricomycetes favor lower $\mathrm{N}$ habitats, with relative abundances inversely related to nitrification rates (Lilleskov et al., 2002). In contrast, the Tremellomycetes Cryptococcus has been characterized as a cellulose degrader (Thongekkaew et al., 2008; Bastias et al., 2009) and orders Cystofilobasidiales and Filobasidiales have the ability to metabolize easily utilizable nutrients (Liu et al., 2015), indicating copiotrophic traits.

\section{Vegetation-Mediated Trophic Niche Differentiation of Soil Microbial Communities along Elevational Gradients}

An additional goal of this study was to determine which soil factors where most related to taxa distributions. Vegetation types that harbored more copiotrophic microbial taxa, including BL$\mathrm{KP}$ forest, BE forest and tundra, were usually characterized by higher soil moisture, $\mathrm{TN}, \mathrm{NO}_{3}^{-}-\mathrm{N}$, SIR, but lower $\mathrm{C} / \mathrm{N}$ ratio, $\mathrm{NH}_{4}^{+}-\mathrm{N}$, and CAI, compared with the two dark-coniferous forests. Thus, relative abundances of copiotrophic microbial taxa were generally correlated with high levels of soil moisture, $\mathrm{TN}, \mathrm{NO}_{3}^{-}-\mathrm{N}, \mathrm{SIR}$, whereas the that of oligotrophic members were associated with high levels of $\mathrm{C} / \mathrm{N}$ ratio, $\mathrm{NH}_{4}^{+}-\mathrm{N}$, and CAI (Figure 7). These observations suggested that these soil parameters may serve as the indicators for predicting the nutrient status of a given ecosystem, and subsequently, the relative abundance of copiotrophic/oligotrophic taxa.

Soil $\mathrm{C} / \mathrm{N}$ ratio can reflect the substrate quality for soil microbial growth, and is proposed as a major factor in determining soil microbial community structure (Rousk et al., 2010). Consistent with the current research, a number of previous studies demonstrated that copiotrophic microbial taxa tended to be more abundant in soils with low $\mathrm{C} / \mathrm{N}$ ratio, and that oligotrophic members preferred habitats with high $\mathrm{C} / \mathrm{N}$ ratios. For example, Proteobacteria was found to be more abundant in medium- $\mathrm{N}$-addition with relative lower $\mathrm{C} / \mathrm{N}$ ratio than in low-N-addition with higher $\mathrm{C} / \mathrm{N}$ ratio (Wang J. et al., 2015). Higher soil $\mathrm{C} / \mathrm{N}$ ratio was found to be associated with higher proportions of Acidobacteria, but lower relative abundance of
Proteobacteria in managed agroecosystems (Wessen et al., 2010). Needle litters generally have higher $\mathrm{C} / \mathrm{N}$ ratio and are more resistant to degradation than leaf litters (Chiti et al., 2012), and thus, higher soil $\mathrm{C} / \mathrm{N}$ ratios are frequently reported in coniferous stands compared with broad leaf stands, or with an increasing proportion of conifers in mixed stands (Barbier et al., 2008; Manzoni et al., 2010).

The soil basal respiration and substrate induced respiration (SIR) are commonly used proxies of the overall activity of soil microorganisms. The respiration rate obtained using the SIR method reflects the short term response, and thus generally captures the activity the fastest growing groups (i.e., $r$ strategists or copiotrophs) (Stenstrom et al., 2001). The RDA analysis revealed that microbial biomass, BR and SIR were all positively associated with the relative abundance of copiotrophic taxa. It was also found that the soil carbon availability (CAI) was positively associated with the relative abundance of oligotrophic taxa. Soils dominated by $\mathrm{K}$ members (oligotrophic microbes) do not require much labile carbon to grow, and thus, show weak response to glucose addition (low SIR and high CAI value). Consequently, the proportion of oligo- or copio-trophic microbial taxa in a microbial community may play important roles in predicting soil organic carbon (SOC) mineralization process, and the subsequent $\mathrm{C}$ balance in the a given ecosystem.

In this study, we found significant correlations between the relative abundances of some specific microbial taxa and soil $\mathrm{pH}$, an edaphic parameter that is frequently used to explain the variations of soil microbial diversity and community compositions (Fierer and Jackson, 2006; Lauber et al., 2008; Ramirez et al., 2010; Shen et al., 2014; Wang J. T. et al., 2015). The correlations between the relative abundances of specific microbial taxa, such as Acidobacteria, Proteobacteria, Bacteroidetes, Ascomycota, and soil $\mathrm{pH}$ have been reported by a variety of previous studies (Lauber et al., 2008; Naether et al., 2012; Meng et al., 2013). Soil pH can be considered as a master variable that integrates a number of other soil and site characteristics, so we do not know whether $\mathrm{pH}$ itself would directly influence microbial community composition, or is indirectly related through other environmental parameters, such as soil parent material (Barton et al., 1994), the composition of litter falls (Bernhard-Reversat, 1999), fertilization (Johnston et al., 1986) and organic matter content (Dahlgren et al., 1997).

We initially hypothesized that the alpine tundra was an oligotrophic habitat, with low temperature, short growing seasons, and low nutrient availability. In contrast to our hypothesis, the AT site exhibited characteristics of a copiotrophic niche in this experiment, evidenced by higher soil $\mathrm{NO}_{3}^{-}-\mathrm{N}$ and $\mathrm{SIR}$, lower $\mathrm{C} / \mathrm{N}$, and higher proportions of potential copiotrophic microbial taxa. High levels of soil available nutrients and the relatively fast $\mathrm{C}$ and $\mathrm{N}$ cycling processes in the alpine zone has been reported in previous studies (Bowman et al., 1993; Frangi et al., 2005; Shen et al., 2016). Higher labile carbon in tundra soils compared to forest soils were also documented on Shennongjia Mountain, China (Ding et al., 2015), in the Fennoscandian mountains (Sjögersten et al., 2003), and at our study site, Changbai Mountain (Zhang et al., 2013; Tian et al., 2014). A survey of soil microbial functional genes on Changbai 
Mountain reported an increase in $\mathrm{C}$ and $\mathrm{N}$ cycling genes at the tree line ecotone, implying the accelerated nutrient cycling in the tundra zone (Shen et al., 2016). Changbai Mountain tundra was shaped by glacial retreat during the Quaternary period, and the plants remaining above $2,000 \mathrm{~m}$ are of polar origin, likely deposited by the melting glaciers (Xu et al., 2004). Because of the low temperature and poor litter quality, plant carbon inputs in tundra soil are very slow (Dai et al., 2002; De Deyn et al., 2008), and this slow carbon allocation may provide sustainable available $\mathrm{C}$ resources to soil microbes. The high nutrients level in tundra soils may also rely on the high proportion of belowground plant carbon (root: shoot ratio of 6.6) (Jackson et al., 1996), which was mainly contained in the soil surface due to permafrost (Jobbagy and Jackson, 2000; Schenk and Jackson, 2002). Moreover, the relative high silt/clay proportion in tundra soil on Changbai Mountain may further help maintain soil nutrient concentrations (Tian et al., 2014). These higher available nutrients in tundra soils likely explain the higher relative abundances of copiotrophic taxa we observed (Figures 2-4). Indeed, previous research has also reported higher proportions of Proteobacteria (or Alphaproteobacteria) in alpine soils than in soils below the tree line (Shahnavaz et al., 2012).

\section{CONCLUSIONS}

The present study revealed that different vegetation types across elevational gradients on the northern slope of Changbai Mountain each harbors distinct soil microbial communities, in terms of both bacteria and fungi composition. In particular, the potential oligotrophic microbial taxa had higher relative abundances in the two dark-coniferous forests at mid-elevation, whereas the forests with more broad leaf trees and alpine tundra had higher relative abundances of copiotrophic taxa. It implied that the elevational patterns of dominant soil microbial taxa

\section{REFERENCES}

Bahram, M., Põlme, S., Kõljalg, U., Zarre, S., and Tedersoo, L. (2012). Regional and local patterns of ectomycorrhizal fungal diversity and community structure along an altitudinal gradient in the Hyrcanian forests of northern Iran. New Phytol. 193, 465-473. doi: 10.1111/j.1469-8137.2011.03927.x

Banning, N. C., Gleeson, D. B., Grigg, A. H., Grant, C. D., Andersen, G. L., Brodie, E. L., et al. (2011). Soil microbial community successional patterns during forest ecosystem restoration. Appl. Environ. Microbiol. 77, 6158-6164. doi: 10.1128/AEM.00764-11

Barbier, S., Gosselin, F., and Balandier, P. (2008). Influence of tree species on understory vegetation diversity and mechanisms involved - A critical review for temperate and boreal forests. For. Ecol. Manage. 254, 1-15. doi: 10.1016/j.foreco.2007.09.038

Barton, D., Hope, D., Billett, M. F., and Cresser, M. S. (1994). Sulphate adsorption capacity and $\mathrm{pH}$ of upland podzolic soils in Scotland: effects of parent material, texture and precipitation chemistry. Appl. Geochem. 9, 127-139. doi: 10.1016/0883-2927(94)90002-7

Bastias, B., Anderson, I., Rangel-Castro, J., Parkin, P., Prosser, J., and Cairney, J. (2009). Influence of repeated prescribed burning on incorporation of $13 \mathrm{C}$ from cellulose by forest soil fungi as determined by RNA stable isotope probing. Soil Biol. Biochem. 41, 467-472. doi: 10.1016/j.soilbio.2008.11.018 along mountain slope were shaped more by vegetation and soil nutrient status. The present study also expands the oligotrophiccopiotrophic theory from dominant bacterial and fungal phyla to the class level, and provided insights into biotic indicators that discriminate different trophic niches. While it is not possible to reliably infer the life strategy of a microbial population based solely on taxonomic catalogs of gene sequences, the oligotrophiccopiotrophic scheme could be used as a theory to synthesize the ever-increasing amount of taxonomic data on soil microbial communities in an ecologically meaningful manner, providing explanations for observed biogeographical patterns.

\section{AUTHOR CONTRIBUTIONS}

HL and XugW designed the research. FY and JY collected soil samples. FY, SY, ZW, XF, and XueW performed the experiments. JY and XugW provided the plant data. FY and HL performed statistical analyses and prepared the draft of the manuscript. YJ and XugW provided intellectual input and advised on the data analyses. JD edited language and advised on the Figures and Tables. All the authors revised the manuscript and approved the final version.

\section{FUNDING}

This work was financially supported by the National Natural Science Foundation of China (31570501 and 41371076), and the Strategic Priority Research Program of the Chinese Academy of Sciences (XDB15010302).

\section{SUPPLEMENTARY MATERIAL}

The Supplementary Material for this article can be found online at: https://www.frontiersin.org/articles/10.3389/fmicb. 2017.02071/full\#supplementary-material

Bellemain, E., Carlsen, T., Brochmann, C., Coissac, E., Taberlet, P., and Kauserud, H. (2010). ITS as an environmental DNA barcode for fungi: an in silico approach reveals potential PCR biases. BMC Microbiol. 10:189. doi: 10.1186/1471-2180-10-189

Bergmann, G. T., Bates, S. T., Eilers, K. G., Lauber, C. L., Caporaso, J. G., Walters, W. A., et al. (2011). The under-recognized dominance of Verrucomicrobia in soil bacterial communities. Soil Biol. Biochem. 43, 1450-1455. doi: 10.1016/j.soilbio.2011.03.012

Bernhard-Reversat, F. (1999). The leaching of Eucalyptus hybrids and Acacia auriculiformis leaf litter: laboratory experiments on early decomposition and ecological implications in congolese tree plantations. Appl. Soil Ecol. 12, 251-261. doi: 10.1016/S0929-1393(99)00005-0

Boone, D., and Castenholz, R. W. (2001). The Archaea and the Deep Branching and Phototrophic Bacteria. New York, NY: Springer.

Bowman, W. D., Theodose, T. A., Schardt, J. C., and Conant, R. T. (1993). Constraints of nutrient availability on primary production in two Alpine Tundra communities. Ecology 74, 2085-2097. doi: 10.2307/1940854

Branco, S., Bruns, T. D., and Singleton, I. (2013). Fungi at a small scale: spatial zonation of fungal assemblages around single trees. PLoS ONE 8:e78295. doi: 10.1371/journal.pone.0078295

Brookes, P. C., Landman, A., Pruden, G., and Jenkinson, D. S. (1985). Chloroform fumigation and thr release of soil-nitrogen - a rapid direct extractiin method 
to measure microbial biomass nitrogen in soil. Soil Biol. Biochem. 17, 837-842. doi: 10.1016/0038-0717(85)90144-0

Bryant, J. A., Lamanna, C., Morlon, H., Kerkhoff, A. J., Enquist, B. J., and Green, J. L. (2008). Microbes on mountainsides: contrasting elevational patterns of bacterial and plant diversity. Proc. Natl. Acad. Sci. U.S.A. 105, 11505-11511. doi: 10.1073/pnas.0801920105

Caporaso, J. G., Lauber, C. L., Walters, W. A., Berg-Lyons, D., Huntley, J., Fierer, N., et al. (2012). Ultra-high-throughput microbial community analysis on the Illumina HiSeq and MiSeq platforms. ISME J. 6, 1621-1624. doi: 10.1038 /ismej.2012.8

Cederlund, H., Wessen, E., Enwall, K., Jones, C. M., Juhanson, J., Pell, M., et al. (2014). Soil carbon quality and nitrogen fertilization structure bacterial communities with predictable responses of major bacterial phyla. Appl. Soil Ecol. 84, 62-68. doi: 10.1016/j.apsoil.2014.06.003

Chiti, T., Diaz-Pines, E., and Rubio, A. (2012). Soil organic carbon stocks of conifers, broadleaf and evergreen broadleaf forests of Spain. Biol. Fertil. Soils 48, 817-826. doi: 10.1007/s00374-012-0676-3

Cho, J.-C., and Giovannoni, S. J. (2004). Cultivation and growth characteristics of a diverse group of oligotrophic marine gammaproteobacteria. Appl. Environ. Microbiol. 70, 432-440. doi: 10.1128/AEM.70.1.432-440.2004

Cleveland, C. C., Nemergut, D. R., Schmidt, S. K., and Townsend, A. R. (2007). Increases in soil respiration following labile carbon additions linked to rapid shifts in soil microbial community composition. Biogeochemistry 82, 229-240. doi: 10.1007/s10533-006-9065-Z

Colpaert, J. V., and vanTichelen, K. K. (1996). Decomposition, nitrogen and phosphorus mineralization from beech leaf litter colonized by ectomycorrhizal or litter-decomposing basidiomycetes. New Phytol. 134, 123-132. doi: 10.1111/j.1469-8137.1996.tb01152.x

Crowther, T. W., Boddy, L., and Jones, T. H. (2012). Functional and ecological consequences of saprotrophic fungus-grazer interactions. ISME J. 6, 1992-2001. doi: 10.1038/ismej.2012.53

Dahlgren, R. A., Boettinger, J. L., Huntington, G. L., and Amundson, R. G. (1997). Soil development along an elevational transect in the western Sierra Nevada, California. Geoderma 78, 207-236. doi: 10.1016/S0016-7061(97) 00034-7

Dai, L. M., Wu, G., Zhao, J. Z., Kong, H. M., Shao, G. F., and Deng, H. B. (2002). Carbon cycling of alpine tundra ecosystems on Changbai Mountain and its comparison with arctic tundra. Sci. China Ser. D. 45, 903-910. doi: 10.1360/02yd9089

De Deyn, G. B., Cornelissen, J. H. C., and Bardgett, R. D. (2008). Plant functional traits and soil carbon sequestration in contrasting biomes. Ecol. Lett. 11, 516-531. doi: 10.1111/j.1461-0248.2008.01164.x

DeBruyn, J. M., Fawaz, M. N., Peacock, A. D., Dunlap, J. R., Nixon, L. T., Cooper, K. E., et al. (2013). Gemmatirosa kalamazoonesis gen. nov., sp. nov., a member of the rarely-cultivated bacterial phylum Gemmatimonadetes. J. Gen. Appl. Microbiol. 59, 305-312. doi: 10.2323/jgam.59.305

DeBruyn, J. M., Nixon, L. T., Fawaz, M. N., Johnson, A. M., and Radosevich, M. (2011). Global biogeography and quantitative seasonal dynamics of Gemmatimonadetes in soil. Appl. Environ. Microbiol. 77, 6295-6300. doi: 10.1128/AEM.05005-11

Dickie, I. A., Xu, B., and Koide, R. T. (2002). Vertical niche differentiation of ectomycorrhizal hyphae in soil as shown by T-RFLP analysis. New Phytol. 156, 527-535. doi: 10.1046/j.1469-8137.2002.00535.x

Dignac, M. F., Bahri, H., Rumpel, C., Rasse, D. P., Bardoux, G., Balesdent, J., et al. (2005). Carbon-13 natural abundance as a tool to study the dynamics of lignin monomers in soil: an appraisal at the Closeaux experimental field (France). Geoderma 128, 3-17. doi: 10.1016/j.geoderma.2004.12.022

Ding, J. J., Zhang, Y. G., Deng, Y., Cong, J., Lu, H., Sun, X., et al. (2015). Integrated metagenomics and network analysis of soil microbial community of the forest timberline. Sci. Rep. 5, 10. doi: 10.1038/srep07994

Eastwood, D. C., Floudas, D., Binder, M., Majcherczyk, A., Schneider, P., Aerts, A., et al. (2011). The plant cell wall-decomposing machinery underlies the functional diversity of forest fungi. Science 333, 762-765. doi: 10.1126/science.1205411

Edgar, R. C., Haas, B. J., Clemente, J. C., Quince, C., and Knight, R. (2011). UCHIME improves sensitivity and speed of chimera detection. Bioinformatics 27, 2194-2200. doi: 10.1093/bioinformatics/btr381
Embley, T. M., and Stackebrandt, E. (1994). The molecular phylogeny and systematics of the actinomycetes. Annu. Rev. Microbiol. 48, 257-289. doi: 10.1146/annurev.mi.48.100194.001353

Fierer, N., and Jackson, R. B. (2006). The diversity and biogeography of soil bacterial communities. Proc. Natl. Acad. Sci. U.S.A. 103, 626-631. doi: 10.1073/pnas.0507535103

Fierer, N., Bradford, M. A., and Jackson, R. B. (2007). Toward an ecological classification of soil bacteria. Ecology 88, 1354-1364. doi: 10.1890/05-1839

Fierer, N., Lauber, C. L., Ramirez, K. S., Zaneveld, J., Bradford, M. A., and Knight, R. (2012). Comparative metagenomic, phylogenetic and physiological analyses of soil microbial communities across nitrogen gradients. ISME J. 6, 1007-1017. doi: 10.1038/ismej.2011.159

Fierer, N., McCain, C. M., Meir, P., Zimmermann, M., Rapp, J. M., Silman, M. R., et al. (2011). Microbes do not follow the elevational diversity patterns of plants and animals. Ecology 92, 797-804. doi: 10.1890/10-1170.1

Francioli, D., Schulz, E., Lentendu, G., Wubet, T., Buscot, F., and Reitz, T. (2016). Mineral vs. organic amendments: microbial community structure, activity and abundance of agriculturally relevant microbes are driven by long-term fertilization strategies. Front. Microbiol. 7:1446. doi: 10.3389/fmicb.2016.01446

Frangi, J. L., Barrera, M. D., Richter, L. L., and Lugo, A. E. (2005). Nutrient cycling in Nothofagus pumilio forests along an altitudinal gradient in Tierra del Fuego, Argentina. For. Ecol. Manage. 217, 80-94. doi: 10.1016/j.foreco.2005.05.051

Frankland, J. C. (1998). Fungal succession - unravelling the unpredictable. Mycol. Res. 102, 1-15. doi: 10.1017/S0953756297005364

Freeman, K. R., Martin, A. P., Karki, D., Lynch, R. C., Mitter, M. S., Meyer, A. F., et al. (2009). Evidence that chytrids dominate fungal communities in high-elevation soils. Proc. Natl. Acad. Sci. U.S.A. 106, 18315-18320. doi: 10.1073/pnas.0907303106

Garrity, G. M., and Holt, J. G. (2001). “The road map to the manual," in Bergey's Manual Of Systematic Bacteriology, eds D. Boone and R. W. Castenholz (New York, NY: Springer), 119-166.

Geml, J., Pastor, N., Fernandez, L., Pacheco, S., Semenova, T. A., Becerra, A. G., et al. (2014). Large-scale fungal diversity assessment in the Andean Yungas forests reveals strong community turnover among forest types along an altitudinal gradient. Mol. Ecol. 23, 2452-2472. doi: 10.1111/mec.12765

Gershenson, A., Bader, N. E., and Cheng, W. X. (2009). Effects of substrate availability on the temperature sensitivity of soil organic matter decomposition. Glob. Change Biol. 15, 176-183. doi: 10.1111/j.1365-2486.2008.01827.x

He, H. S., Hao, Z. Q., Mladenoff, D. J., Shao, G. F., Hu, Y. M., and Chang, Y. (2005). Simulating forest ecosystem response to climate warming incorporating spatial effects in north-eastern China. J. Biogeogr. 32, 2043-2056. doi: 10.1111/j.1365-2699.2005.01353.x

Hibbett, D. S., Gilbert, L.-B., and Donoghue, M. J. (2000). Evolutionary instability of ectomycorrhizal symbioses in basidiomycetes. Nature 407, 506-508. doi: $10.1038 / 35035065$

Högberg, M. N., Bååth, E., Nordgren, A., Arnebrant, K., and Högberg, P. (2003). Contrasting effects of nitrogen availability on plant carbon supply to mycorrhizal fungi and saprotrophs-a hypothesis based on field observations in boreal forest. New Phytol. 160, 225-238. doi: 10.1046/j.1469-8137.2003.00867.x

Jackson, R. B., Canadell, J., Ehleringer, J. R., Mooney, H. A., Sala, O. E., and Schulze, E. D. (1996). A global analysis of root distributions for terrestrial biomes. Oecologia 108, 389-411. doi: 10.1007/BF00333714

Janssen, P. H., Schuhmann, A., Morschel, E., and Rainey, F. A. (1997). Novel anaerobic ultramicrobacteria belonging to the Verrucomicrobiales lineage of bacterial descent isolated by dilution culture from anoxic rice paddy soil. Appl. Environ. Microbiol. 63, 1382-1388.

Janssen, P. H., Yates, P. S., Grinton, B. E., Taylor, P. M., and Sait, M. (2002). Improved culturability of soil bacteria and isolation in pure culture of novel members of the divisions Acidobacteria, Actinobacteria, Proteobacteria, and Verrucomicrobia. Appl. Environ. Microbiol. 68, 2391-2396. doi: 10.1128/AEM.68.5.2391-2396.2002

Jobbagy, E. G., and Jackson, R. B. (2000). The vertical distribution of soil organic carbon and its relation to climate and vegetation. Ecol. Appl. 10, 423-436. doi: 10.1890/1051-0761(2000)010[0423:TVDOSO]2.0.CO;2

Johnston, A. E., Goulding, K. W. T., and Poulton, P. R. (1986). Soil acidification during more than 100 years under permanent grassland and woodland at Rothamsted. Soil Use Manage. 2, 3-10. doi: 10.1111/j.1475-2743.1986.tb00669.x 
King, A. J., Farrer, E. C., Suding, K. N., and Schmidt, S. K. (2012). Cooccurrence patterns of plants and soil bacteria in the high-alpine subnival zone track environmental harshness. Front. Microbiol. 3:347. doi: 10.3389/fmicb.2012.00347

Knorr, M., Frey, S. D., and Curtis, P. S. (2005). Nitrogen additions and litter decomposition: a meta-analysis. Ecology 86, 3252-3257. doi: 10.1890/05-0150

Kohler, A., Kuo, A., Nagy, L. G., Morin, E., Barry, K. W., Buscot, F., et al. (2015). Convergent losses of decay mechanisms and rapid turnover of symbiosis genes in mycorrhizal mutualists. Nat. Genet. 47, 410-415. doi: 10.1038/ng.3223

Lauber, C. L., Strickland, M. S., Bradford, M. A., and Fierer, N. (2008). The influence of soil properties on the structure of bacterial and fungal communities across land-use types. Soil Biol. Biochem. 40, 2407-2415. doi: 10.1016/j.soilbio.2008.05.021

Leake, J. R., Donnelly, D. P., and Boddy, L. (2003). "Interactions between ectomycorrhizal and saprotrophic fungi", in Mycorrhizal Ecology eds M. G. A. Heijden and I. R. Sanders(Berlin: Springer-Verlag), 345-371.

Leff, J. W., Jones, S. E., Prober, S. M., Barberan, A., Borer, E. T., Firn, J. L., et al. (2015). Consistent responses of soil microbial communities to elevated nutrient inputs in grasslands across the globe. Proc. Natl. Acad. Sci. U.S.A. 112, 10967-10972. doi: 10.1073/pnas.1508382112

Li, H., Xu, Z., Yang, S., Li, X., Top, E. M., Wang, R., et al. (2016). Responses of soil bacterial communities to nitrogen deposition and precipitation increment are closely linked with aboveground community variation. Microb. Ecol. 71, 974-989. doi: 10.1007/s00248-016-0730-z

Li, H., Ye, D., Wang, X., Settles, M. L., Wang, J., Hao, Z., et al. (2014). Soil bacterial communities of different natural forest types in Northeast China. Plant Soil 383, 203-216. doi: 10.1007/s11104-014-2165-y

Lievens, B., Hallsworth, J. E., Pozo, M. I., Belgacem, Z. B., Stevenson, A., Willems, K. A., et al. (2015). Microbiology of sugar-rich environments: diversity, ecology and system constraints. Environ. Microbiol. 17, 278-298. doi: $10.1111 / 1462-2920.12570$

Lilleskov, E. A., Fahey, T. J., and Lovett, G. M. (2001). Ectomycorrhizal fungal aboveground community change over an atmospheric nitrogen deposition gradient. Ecol. Appl. 11, 397-410. doi: 10.1890/10510761(2001)011 [0397:EFACCO]2.0.CO;2

Lilleskov, E. A., Fahey, T. J., Horton, T. R., and Lovett, G. M. (2002). Belowground ectomycorrhizal fungal community change over a nitrogen deposition gradient in Alaska. Ecology 83, 104-115. doi: 10.1890/00129658(2002)083[0104:BEFCCO]2.0.CO;2

Lindahl, B. D., Ihrmark, K., Boberg, J., Trumbore, S. E., Hogberg, P., Stenlid, J., et al. (2007). Spatial separation of litter decomposition and mycorrhizal nitrogen uptake in a boreal forest. New Phytol. 173, 611-620. doi: $10.1111 / j .1469-8137.2006 .01936 . x$

Linnaeus, C. (1781). On the increase of the habitable earth. Amoenitates Academicae 2, 17-27.

Liu, X. Z., Wang, Q. M., Theelen, B., Groenewald, M., Bai, F. Y., and Boekhout, T. (2015). Phylogeny of tremellomycetous yeasts and related dimorphic and filamentous basidiomycetes reconstructed from multiple gene sequence analyses. Stud. Mycol.81, 1-26. doi: 10.1016/j.simyco.2015.08.001

Llado, S., Zifcakova, L., Vetrovsky, T., Eichlerova, I., and Baldrian, P. (2016). Functional screening of abundant bacteria from acidic forest soil indicates the metabolic potential of Acidobacteria subdivision 1 for polysaccharide decomposition. Biol. Fertil. Soils 52, 251-260. doi: 10.1007/s00374-015-1072-6

Manzoni, S., Trofymow, J. A., Jackson, R. B., and Porporato, A. (2010). Stoichiometric controls on carbon, nitrogen, and phosphorus dynamics in decomposing litter. Ecol. Monogr. 80, 89-106. doi: 10.1890/09-0179.1

McGuire, K. L., Allison, S. D., Fierer, N., and Treseder, K. K. (2013). Ectomycorrhizal-dominated boreal and tropical forests have distinct fungal communities, but analogous spatial patterns across soil horizons. PLoS ONE 8:e68278. doi: 10.1371/journal.pone.0068278

Meier, C. L., Rapp, J., Bowers, R. M., Silman, M., and Fierer, N. (2010). Fungal growth on a common wood substrate across a tropical elevation gradient: temperature sensitivity, community composition, and potential for above-ground decomposition. Soil Biol. Biochem. 42, 1083-1090. doi: 10.1016/j.soilbio.2010.03.005

Meng, H., Li, K., Nie, M., Wan, J. R., Quan, Z. X., Fang, C. M., et al. (2013). Responses of bacterial and fungal communities to an elevation gradient in a subtropical montane forest of China. Appl. Microb. Biotechnol. 97, 2219-2230. doi: 10.1007/s00253-012-4063-7
Muller, M., Oelmann, Y., Schickhoff, U., Bohner, J., and Scholten, T. (2017). Himalayan treeline soil and foliar C:N:P stoichiometry indicate nutrient shortage with elevation. Geoderma 291, 21-32. doi: 10.1016/j.geoderma.2016.12.015

Naether, A., Foesel, B. U., Naegele, V., Wuest, P. K., Weinert, J., Bonkowski, M., et al. (2012). Environmental factors affect acidobacterial communities below the subgroup level in grassland and forest soils. Appl. Environ. Microbiol. 78, 7398-7406. doi: 10.1128/AEM.01325-12

Navarrete, A. A., Venturini, A. M., Meyer, K. M., Klein, A. M., Tiedje, J. M., Bohannan, B. J. M., et al. (2015). Differential response of Acidobacteria subgroups to forest-to-pasture conversion and their biogeographic patterns in the western Brazilian Amazon. Front. Microbiol. 6:1443. doi: $10.3389 /$ fmicb. 2015.01443

Nemergut, D. R., Cleveland, C. C., Wieder, W. R., Washenberger, C. L., and Townsend, A. R. (2010). Plot-scale manipulations of organic matter inputs to soils correlate with shifts in microbial community composition in a lowland tropical rain forest. Soil Biol. Biochem. 42, 2153-2160. doi: 10.1016/j.soilbio.2010.08.011

Nugroho, R. A., Roling, W. F. M., Laverman, A. M., Zoomer, H. R., and Verhoef, H. A. (2005). Presence of Nitrosospira cluster 2 bacteria corresponds to $\mathrm{N}$ transformation rates in nine acid Scots pine forest soils. FEMS Microbiol. Ecol. 53, 473-481. doi: 10.1016/j.femsec.2005.02.002

Nunes da Rocha, U., Plugge, C. M., George, I., van Elsas, J. D., and van Overbeek, L. S. (2013). The Rhizosphere Selects for Particular Groups of Acidobacteria and Verrucomicrobia. PLoS ONE 8:e82443. doi: 10.1371/journal.pone.0082443

Ohsawa, T., and Ide, Y. (2008). Global patterns of genetic variation in plant species along vertical and horizontal gradients on mountains. Glob. Ecol. Biogeogr. 17, 152-163. doi: 10.1111/j.1466-8238.2007.00357.x

Pan, Y., Cassman, N., de Hollander, M., Mendes, L. W., Korevaar, H., Geerts, R., et al. (2014). Impact of long-term N, P, K, and NPK fertilization on the composition and potential functions of the bacterial community in grassland soil. FEMS Microbiol. Ecol. 90, 195-205. doi: 10.1111/1574-6941. 12384

Phung, N. T., Lee, J., Kang, K. H., Chang, I. S., Gadd, G. M., and Kim, B. H. (2004). Analysis of microbial diversity in oligotrophic microbial fuel cells using 16S rDNA sequences. FEMS Microbiol. Lett. 233, 77-82. doi: 10.1016/j.femsle.2004.01.041

Pyrcz, T. W., Wojtusiak, J., and Garlacz, R. (2009). Diversity and distribution patterns of Pronophilina butterflies (Lepidoptera: Nymphalidae: Satyrinae) along an altitudinal transect in north-western Ecuador. Neotrop. Entomol. 38, 716-726. doi: 10.1590/S1519-566X2009000600003

Ramirez, K. S., Craine, J. M., and Fierer, N. (2012). Consistent effects of nitrogen amendments on soil microbial communities and processes across biomes. Glob. Change Biol. 18, 1918-1927. doi: 10.1111/j.1365-2486.2012.02639.x

Ramirez, K. S., Lauber, C. L., Knight, R., Bradford, M. A., and Fierer, N. (2010). Consistent effects of nitrogen fertilization on soil bacterial communities in contrasting systems. Ecology 91, 3463-3470. doi: 10.1890/100426.1

Ramirez-Villanueva, D. A., Bello-López, J. M., Navarro-Noya, Y. E., Luna-Guido, M., Verhulst, N., Govaerts, B., et al. (2015). Bacterial community structure in maize residue amended soil with contrasting management practices. Appl. Soil Ecol. 90, 49-59. doi: 10.1016/j.apsoil.2015. 01.010

Read, D. J., and Perez-Moreno, J. (2003). Mycorrhizas and nutrient cycling in ecosystems - a journey towards relevance? New Phytol. 157, 475-492. doi: 10.1046/j.1469-8137.2003.00704.x

Rousk, J., Baath, E., Brookes, P. C., Lauber, C. L., Lozupone, C., Caporaso, J. G., et al. (2010). Soil bacterial and fungal communities across a $\mathrm{pH}$ gradient in an arable soil. ISME J. 4, 1340-1351. doi: 10.1038/ismej.2010.58

Rowe, R. J. (2009). Environmental and geometric drivers of small mammal diversity along elevational gradients in Utah. Ecography 32, 411-422. doi: 10.1111/j.1600-0587.2008.05538.x

Roy, J., Albert, C. H., Ibanez, S., Saccone, P., Zinger, L., Choler, P., et al. (2013). Microbes on the cliff: alpine cushion plants structure bacterial and fungal communities. Front. Microbiol. 4:64. doi: 10.3389/fmicb.2013. 00064

Schenk, H. J., and Jackson, R. B. (2002). The global biogeography of roots. Ecol. Monogr. 72, 311-328. doi: 10.1890/0012-9615(2002)072[0311:TGBOR]2. $0 . \mathrm{CO} ; 2$ 
Shahnavaz, B., Zinger, L., Lavergne, S., Choler, P., and Geremia, R. A. (2012). Phylogenetic clustering reveals selective events driving the turnover of bacterial community in alpine tundra soils. Arct. Antarct. Alp. Res. 44, 232-238. doi: 10.1657/1938-4246-44.2.232

Shen, C. C., Liang, W. J., Shi, Y., Lin, X. G., Zhang, H. Y., Wu, X., et al. (2014). Contrasting elevational diversity patterns between eukaryotic soil microbes and plants. Ecology 95, 3190-3202. doi: 10.1890/14-0310.1

Shen, C. C., Shi, Y., Ni, Y. Y., Deng, Y., Van Nostrand, J. D., He, Z. L., et al. (2016). Dramatic increases of soil microbial functional gene diversity at the treeline ecotone of changbai mountain. Front. Microbiol. 7:1184. doi: 10.3389/fmicb.2016.01184

Shen, C., Xiong, J., Zhang, H., Feng, Y., Lin, X., Li, X., et al. (2013). Soil pH drives the spatial distribution of bacterial communities along elevation on Changbai Mountain. Soil Biol. Biochem. 57, 204-211. doi: 10.1016/j.soilbio.2012.07.013

Singh, D., Shi, L., and Adams, J. M. (2013). Bacterial diversity in the mountains of South-West China: climate dominates over soil parameters. J. Microbiol. 51, 439-447. doi: 10.1007/s12275-013-2446-9

Singh, D., Takahashi, K., Kim, M., Chun, J., and Adams, J. M. (2012). A humpbacked trend in bacterial diversity with elevation on Mount Fuji, Japan. Microb. Ecol. 63, 429-437. doi: 10.1007/s00248-011-9900-1

Sjögersten, S., Turner, B. L., Mahieu, N., Condron, L. M., and Wookey, P. A. (2003). Soil organic matter biochemistry and potential susceptibility to climatic change across the forest-tundra ecotone in the Fennoscandian mountains. Glob. Change Biol. 9, 759-772. doi: 10.1046/j.1365-2486.2003.00598.x

Smit, E., Leeflang, P., Gommans, S., van den Broek, J., van Mil, S., and Wernars, K. (2001). Diversity and seasonal fluctuations of the dominant members of the bacterial soil community in a wheat field as determined by cultivation and molecular methods. Appl. Environ. Microbiol. 67, 2284-2291. doi: 10.1128/AEM.67.5.2284-2291.2001

Smith, S. E., and Read, D. J. (2008). Mycorrhizal Symbiosis, 3rd Edn. London: Academic Press.

Stenstrom, J., Svensson, K., and Johansson, M. (2001). Reversible transition between active and dormant microbial states in soil. FEMS Microbiol. Ecol. 36, 93-104. doi: 10.1016/S0168-6496(01)00122-2

Tedersoo, L., May, T. W., and Smith, M. E. (2010). Ectomycorrhizal lifestyle in fungi: global diversity, distribution, and evolution of phylogenetic lineages. Mycorrhiza 20, 217-263. doi: 10.1007/s00572-009-0274-x

Thongekkaew, J., Ikeda, H., Masaki, K., and Iefuji, H. (2008). An acidic and thermostable carboxymethyl cellulase from the yeast Cryptococcus sp. S-2: purification, characterization and improvement of its recombinant enzyme production by high cell-density fermentation of Pichia pastoris. Protein Expr. Purif. 60, 140-146. doi: 10.1016/j.pep.2008.03.021

Tian, Q., He, H., Cheng, W., and Zhang, X. (2014). Pulse-dynamic and monotonic decline patterns of soil respiration in long term laboratory microcosms. Soil Biol. Biochem. 68, 329-336. doi: 10.1016/j.soilbio.2013.10.015

Treseder, K. K. (2004). A meta-analysis of mycorrhizal responses to nitrogen, phosphorus, and atmospheric CO2 in field studies. New Phytol. 164, 347-355. doi: 10.1111/j.1469-8137.2004.01159.x

Wang, J. T., Zheng, Y. M., Hu, H. W., Zhang, L. M., Li, J., and He, J. Z. (2015). Soil $\mathrm{pH}$ determines the alpha diversity but not beta diversity of soil fungal community along altitude in a typical Tibetan forest ecosystem. J. Soils Sed. 15, 1224-1232. doi: 10.1007/s11368-015-1070-1

Wang, J., Bao, J. T., Su, J. Q., Li, X. R., Chen, G. X., and Ma, X. F. (2015). Impact of inorganic nitrogen additions on microbes in biological soil crusts. Soil Biol. Biochem. 88, 303-313. doi: 10.1016/j.soilbio.2015.06.004

Wang, Q., Garrity, G. M., Tiedje, J. M., and Cole, J. R. (2007). Naive Bayesian classifier for rapid assignment of rRNA sequences into the new bacterial taxonomy. Appl. Environ. Microbiol. 73, 5261-5267. doi: 10.1128/AEM.00062-07
Ward, N. L., Challacombe, J. F., Janssen, P. H., Henrissat, B., Coutinho, P. M., Wu, M., et al. (2009). Three genomes from the phylum Acidobacteria provide insight into the lifestyles of these microorganisms in soils. Appl. Environ. Microbiol. 75, 2046-2056. doi: 10.1128/AEM.02294-08

Weisburg, W. G., Barns, S. M., Pelletier, D. A., and Lane, D. J. (1991). 16S ribosomal DNA amplification for phylogenetic study. J. Bacteriol. 173, 697-703. doi: 10.1128/jb.173.2.697-703.1991

Wessen, E., Hallin, S., and Philippot, L. (2010). Differential responses of bacterial and archaeal groups at high taxonomical ranks to soil management. Soil Biol. Biochem. 42, 1759-1765. doi: 10.1016/j.soilbio.2010.06.013

Wichern, F., Mayer, J., Joergensen, R. G., and Muller, T. (2007). Release of C and $\mathrm{N}$ from roots of peas and oats and their availability to soil microorganisms. Soil Biol. Biochem. 39, 2829-2839. doi: 10.1016/j.soilbio.2007.06.006

$\mathrm{Xu}$, W., He, X., Chen, W., and Liu, C. (2004). Characteristics and succession rules of vegetation types in Changbai Mountain. Chin. J. Ecol. 23, $162-174$.

Zhang, B., Liang, C., He, H. B., and Zhang, X. D. (2013). Variations in Soil Microbial Communities and Residues Along an Altitude Gradient on the Northern Slope of Changbai Mountain, China. PLoS ONE 8:e66184. doi: 10.1371/journal.pone.0066184

Zhang, H., Sekiguchi, Y., Hanada, S., Hugenholtz, P., Kim, H., Kamagata, Y., et al. (2003). Gemmatimonas aurantiaca gen. nov., sp. nov., a Gramnegative, aerobic, polyphosphate-accumulating micro-organism, the first cultured representative of the new bacterial phylum Gemmatimonadetes phyl. nov. Int. J. Syst. Evol. Microbiol. 53, 1155-1163. doi: 10.1099/ijs.0.02520-0

Zhang, M., Liang, W.-J., and Zhang, X.-K. (2012). Soil nematode abundance and diversity in different forest types at Changbai Mountain, China. Zool. Stud. 51, 619-626.

Zhang, M., Zhang, X. K., Liang, W. J., Jiang, Y., Dai, G. H., Wang, X. G., et al. (2011). Distribution of Soil Organic Carbon Fractions Along the Altitudinal Gradient in Changbai Mountain, China. Pedosphere 21, 615-620. doi: 10.1016/S1002-0160(11)60163-X

Zhang, W., Chao, L., Yang, Q., Wang, Q., Fang, Y., and Wang, S. (2016). Litter quality mediated nitrogen effect on plant litter decomposition regardless of soil fauna presence. Ecology 97, 2834-2843. doi: 10.1002/ecy.1515

Zhang, Y. G., Cong, J., Lu, H., Li, G. L., Xue, Y. D., Deng, Y., et al. (2015). Soil bacterial diversity patterns and drivers along an elevational gradient on Shennongjia Mountain, China. Microb. Biotechnol. 8, 739-746. doi: 10.1111/1751-7915.12288

Zhao, J., Ni, T., Li, Y., Xiong, W., Ran, W., Shen, B., et al. (2014). Responses of bacterial communities in arable soils in a rice-wheat cropping system to different fertilizer regimes and sampling times. PLoS ONE 9:e85301. doi: 10.1371/journal.pone.0085301

Zinger, L., Lejon, D. P., Baptist, F., Bouasria, A., Aubert, S., Geremia, R. A., et al. (2011). Contrasting diversity patterns of crenarchaeal, bacterial and fungal soil communities in an alpine landscape. PLOS ONE 6:e19950. doi: 10.1371/journal.pone.0019950

Conflict of Interest Statement: The authors declare that the research was conducted in the absence of any commercial or financial relationships that could be construed as a potential conflict of interest.

Copyright (C) 2017 Yao, Yang, Wang, Wang, Ye, Wang, DeBruyn, Feng, Jiang and Li. This is an open-access article distributed under the terms of the Creative Commons Attribution License (CC BY). The use, distribution or reproduction in other forums is permitted, provided the original author(s) or licensor are credited and that the original publication in this journal is cited, in accordance with accepted academic practice. No use, distribution or reproduction is permitted which does not comply with these terms. 